\title{
Do markets encourage risk-seeking behaviour?
}

Citation for published version (APA):

Mengel, F., \& Peeters, R. J. A. P. (2015). Do markets encourage risk-seeking behaviour? Maastricht University, Graduate School of Business and Economics. GSBE Research Memoranda No. 042 https://doi.org/10.26481/umagsb.2015042

Document status and date:

Published: 01/01/2015

DOI:

10.26481/umagsb.2015042

Document Version:

Publisher's PDF, also known as Version of record

\section{Please check the document version of this publication:}

- A submitted manuscript is the version of the article upon submission and before peer-review. There can be important differences between the submitted version and the official published version of record.

People interested in the research are advised to contact the author for the final version of the publication, or visit the DOI to the publisher's website.

- The final author version and the galley proof are versions of the publication after peer review.

- The final published version features the final layout of the paper including the volume, issue and page numbers.

Link to publication

\footnotetext{
General rights rights.

- You may freely distribute the URL identifying the publication in the public portal. please follow below link for the End User Agreement:

www.umlib.nl/taverne-license

Take down policy

If you believe that this document breaches copyright please contact us at:

repository@maastrichtuniversity.nl

providing details and we will investigate your claim.
}

Copyright and moral rights for the publications made accessible in the public portal are retained by the authors and/or other copyright owners and it is a condition of accessing publications that users recognise and abide by the legal requirements associated with these

- Users may download and print one copy of any publication from the public portal for the purpose of private study or research.

- You may not further distribute the material or use it for any profit-making activity or commercial gain

If the publication is distributed under the terms of Article $25 \mathrm{fa}$ of the Dutch Copyright Act, indicated by the "Taverne" license above, 


\section{Maastricht University}

Friederike Mengel, Ronald Peeters

Do markets encourage riskseeking behaviour?

$\mathrm{RM} / 15 / 042$

\section{GSBE}

Maastricht University School of Business and Economics

Graduate School of Business and Economics

P.O Box 616

NL-6200 MD Maastricht

The Netherlands 


\title{
Do markets encourage risk-seeking behaviour?*
}

\author{
Friederike Mengel ${ }^{\dagger} \quad$ Ronald PeEters ${ }^{\ddagger}$ \\ University of Essex and \\ Maastricht University \\ Maastricht University
}

December 2015

\begin{abstract}
Excessive risk taking in markets can have devastating consequences as recent financial crises have highlighted. In this paper we ask whether markets as an institution encourage such excessive risk taking. To establish causality, we isolate the effects of market interaction in a laboratory experiment keeping other possibly confounding factors constant. We find that the opposite is true. Markets decrease participants' willingness to take risks. This finding can be explained by social comparison utility in the presence of negatively correlated risks and we provide evidence for such a mechanism.
\end{abstract}

Keywords: Markets; Risk-taking; Social comparison; Experiment.

JEL Classification Numbers: D02; D03.

${ }^{*}$ We thank Paulo Rodrigues, Ulrich Schmidt, Paul Smeets, Nora Szech, Marc Vorsatz, Joel van der Weele and Leonard Wolk for very helpful comments and suggestions. The Netherlands Organisation for Scientific Research (NWO) is gratefully acknowledged for its support.

${ }^{\dagger}$ Department of Economics, University of Essex, Wivenhoe Park, Colchester CO4 3SQ. e-mail: fr.mengel@gmail.com.

${ }^{\ddagger}$ Department of Economics, Maastricht University, Tongersestraat 53, 6211 LM Maastricht. e-mail: r.peeters@maastrichtuniversity.nl. 


\section{Introduction}

Markets are ubiquitous in modern society (North, 1991). We interact in markets to trade goods, services and information and they affect most aspects of our everyday life. Markets have been praised for their ability to efficiently aggregate expectations and information from disparate traders, thereby allocating resources more efficiently than central authority and governments (Hayek, 1945). However, there is a dark side as well. Evidence that market interactions may go along with the risk of moral decay has recently been the subject of a keen debate in politics, ethics and in the social sciences, including economics (Shleifer, 2004; Falk and Szech, 2013; Bartling et al., 2015). One particular aspect of moral hazard that received increasing attention during the latest economic crisis is that incentives provided by markets may encourage risk taking behaviour (Bernanke, 2008; Porcelli and Delgado, 2009; Dong et al., 2010). Indeed, certain key aspects of many markets, such as competition, have traditionally been considered a source of excessive risk taking (Matutes and Vives, 2000). Excessive risk taking behaviour can impose negative externalities on society, such as mispricing of goods and services and risks of bankruptcy, financial contagion and crises with correspondingly large losses for society (Reinhart and Rogoff, 2009).

In this study, we investigate whether markets induce risk taking behaviour. The ideal experiment to identify a causal effect of markets on risk taking behaviour involves the comparison of different institutions at the same time in identical, but distinct societies with no interactions or feedback effects between them. To come as close as possible to this ideal, we conducted a laboratory experiment in which we randomly assign subjects to different institutional environments. In treatments with market interaction (the market treatments) assets are traded via a call auction mechanism (Plott and Smith, 2008). In the non-market treatments prices of assets are determined via a BDM mechanism. In all treatments two assets are traded in parallel markets, where one asset is more risky than the other in the sense of mean-preserving spreads. Risk taking behaviour is measured by studying and comparing the prices of these two assets. The information available to participants across these treatment variations is exactly identical. The only difference is how prices are determined. Both treatments exist in two versions: one where information about the outcomes of other market participants is provided and one where such social comparison information is absent. This completes our $2 \times 2$ design.

Somewhat surprisingly, we find that markets decrease participants' willingness to take risks. This is the case, however, if and only if information about the outcomes of other market participants is provided. In the absence of such social comparison information, risk premia in markets do not differ from those in the non-market settings. These findings can be explained by social comparison utility in the presence of negatively correlated risks. We discuss this as well as other possible mechanisms.

Our results contribute to two different strands of literature, one focusing on how social comparison affects behaviour in market settings and another one focused on the determinants of risk premia in markets.

Gortner and van der Weele (2015) study willingness to take risks in a portfolio choice setting designed to test the Arrow-Debreu predictions on risk-sharing. They find that both imitation and positional preferences play a role for risk-taking. Unlike our study, they do not compare markets with equivalent non-market settings. A second important difference is that in their design, trades do not imply negative correlation of risk. The correlation structure of risk is crucial to predict how social comparison is expected to affect risk premia. Literature on experimental asset markets has often focused on bubble formation. Within that setting both Oechssler et al. (2011) and Schoenberg and Haruvy (2012) have asked how social comparison information affects the prevalence of price bubbles. Schoenberg and Haruvy (2012) find that observing the 
earnings of the highest earning market participant increases the prevalence of bubbles. There are also a number of field studies using information on social ties or the spatial distribution of traders to establish that peer decisions matter for stock market participation and trading decisions (Hong et al., 2005; Bursztyn et al., 2014).

To our knowledge there is only one paper comparing markets with equivalent non-market settings in a laboratory experiment. This study by Bohm et al. (1997), however, focuses on how to best design a BDM mechanism in order to elicit prices that differ as little as possible from the corresponding market design. Our study shows that any such comparison will depend on whether social comparison information is provided. While the market and the BDM setting yield the same risk premia in the absence of social comparison information, this is no longer the case once such information is provided. Two other recent studies compared market and non-market interaction in settings in which studying risk-taking behaviour is not easily possible. Falk and Szech (2013) study morality in markets by comparing a setting where individuals make a decision about whether or not to avoid the killing of a mouse at a monetary cost and one where the decision involved trading in a double auction market. They found that more mice were killed in the market setting concluding that markets erode morals. Bartling et al. (2015) study social responsibility in markets. They compare single person allocation tasks (like dictator games) as non-market settings with product markets where low-cost production creates negative externalities. While each of these studies produces interesting results on morality in markets, their designs are not suited to (nor meant to) study risk-taking behaviour.

Our study also points to social comparison utility as one important channel affecting risk premia. It hence contributes to a larger literature trying to understand what determines risk premia in financial decision making. Within this context particularly related are Campbell and Cochrane (1999), Wachter (2006) or Aldrich and Gallant (2011) who show that models involving habit formation can explain asset prices and short- and long-run equity premium puzzles.

This paper is organized as follows. Section 2 introduces our experimental design. Section 3 presents the main results. Section 4 discusses mechanisms and Section 5 concludes.

\section{Methods}

The ideal experiment to identify a causal effect of markets on risk taking behaviour involves the comparison of different institutions at the same time in identical, but distinct societies with no interactions or feedback effects between them. To come as close as possible to this ideal, we conducted a laboratory experiment in which we randomly assign subjects to different institutional environments. In order to isolate the effect of market interaction, we implemented two institutional settings with equal decision frameworks, incentives and informational conditions, and that only differed in whether subjects' incentives were based on market interactions or not. In both environments, a group of five agents traded assets in two parallel but isolated markets. In each trading period all agents started with one unit of each asset in stock. Next, they simultaneously and independently specified for each asset their selling price and buying price. The selling price indicates for which price they are willing to sell their unit; the buying price indicates for which price they are willing to buy a second unit.

In the treatments with market interaction (the market treatments) assets are traded via a call auction mechanism (Plott and Smith, 2008). Trade occurs when some subject's buying price is above another subject's selling price. The market price is the price at which all possible trades can take place simultaneously. 
In case no trade is possible (i.e. when the highest buying price is below the lowest selling price), no market price is determined; when there are multiple prices at which the market clears, the market price is the average of these. After each trading period, subjects are informed about the market price.

In the treatments without market interaction (the nonmarket treatments), purchases and sales of stocks were determined according to a Becker-DeGroot-Marschak (BDM) mechanism (Becker et al., 1964). Instead of assets being bought or sold at the market price, subjects' purchases and sales were determined by a randomly drawn price. Subjects with a selling price below the random price sell their unit and those with a buying price above this random price buy a second unit. To equalize the information flow with the market treatment, the fictitious market price was communicated after each trading period. ${ }^{1}$

In all treatments subjects interacted within fixed groups during three repetitions of ten trading periods. At the beginning of each repetition all subjects were informed that each asset has a return of either 50, 100 or 150, but they did not know the probability distribution of returns. The probabilities associated with these three outcomes were $1 / 5,3 / 5$ and $1 / 5$ for one asset and $2 / 5,1 / 5$ and $2 / 5$ for the other asset. Hence, both assets had an equal expected value of 100, but differed in riskiness: one asset was more risky than the other in the sense of mean-preserving spreads. Each subject received one possible return value as a signal and they knew that the probability to receive a particular return value as signal was equal to the probability that the asset returns this value. Hence, even though the signal is far from perfect, it is informative. Signals were randomly allocated in such a manner that on aggregate perfect information on the return probabilities was available in the group. The fact that there are no information asymmetries means our design is less conducive to strategic manipulation. The asset markets and signal distributions were kept constant within each repetition, but varied across repetitions (Appendix A).

Both the market and the nonmarket treatments were run in two informational variations: one where after each trading period subjects were informed about others' buying and asking prices (with social comparison (SC) information), and one where they did not receive such information (without SC information). The former mimics markets with higher transparency where traders typically know each others' market outcomes, such as many exchange markets or online trading platforms (zulutrade.com, etoro.com) where other trader's outcomes can be observed. The latter is closer to more opaque markets where little information about others' outcomes is available, such as some over-the-counter (OTC) markets or dark pools.

The experiments were conducted in the BEElab, the experimental laboratory at Maastricht University, in November 2014 and June 2015. We recruited undergraduate students from various disciplines via ORSEE (Greiner, 2004). All interactions took place anonymously via computer clients that where connected to a central server using z-Tree (Fischbacher, 2007). Instructions and screenshots are provided in Appendices B and C. At the end of the experiment, subjects participated in a short questionnaire in which we elicited a few personal characteristics (see Appendix D). In total, 160 students participated in the experiment: 8 groups of five per treatment (see Appendix E for information on our subject pool). A typical session lasted about 90 minutes and the average payoff was 15.26 Euros (including a 5.00 Euro show-up fee).

\footnotetext{
${ }^{1}$ There has been some discussion on whether the BDM mechanism is incentive compatible under non-expected utility preferences (Karni and Safra, 1987). As will become clear below in our experiment we only use the mechanism in a treatment comparison with the market setting and not to e.g. elicit certainty equivalents. Hence, whether or not the mechanism is incentive compatible is not of primary importance for the present purpose.
} 


\section{Results}

We are interested in the extent of risk-taking across the four conditions. We measure the extent of risktaking by the premium participants require to incur risks. A risk premium is usually defined as the return in excess of the risk-free rate an asset is expected to yield to compensate the investor for the risk $\mathrm{s} / \mathrm{he}$ is taking. Since both assets in our setting yield the same expected return, we define the risk premium here as the difference in market price between the less and the more risky asset. This risk premium thus defined measures how much the market values avoiding risk. If incentives created by market interactions were to encourage risk seeking behaviour, we should observe a lower risk premium in the market treatment than in the nonmarket treatment.

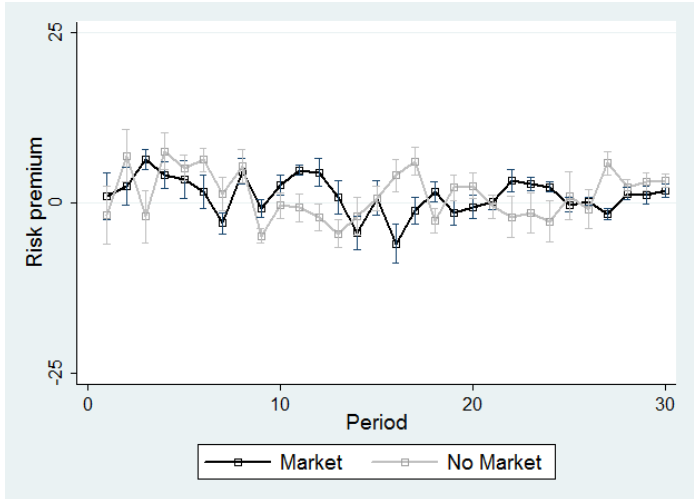

(a) without SC information

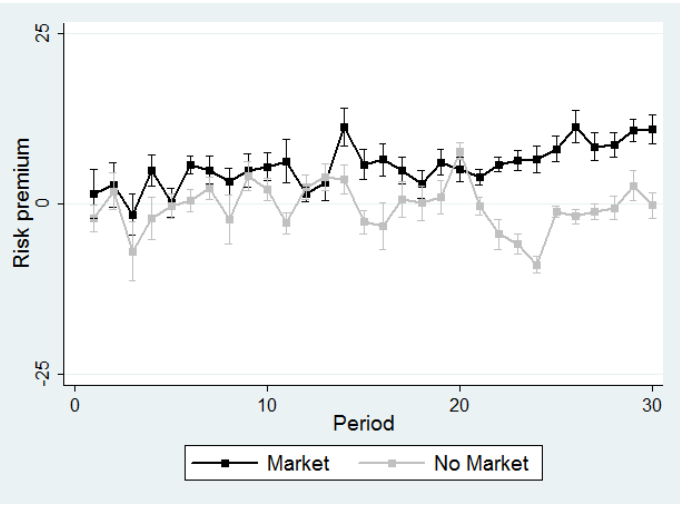

(b) with SC information

Figure 1: Development of average risk premium in the different treatments.

Figure 1 shows the average risk premium over time in the treatment with (black) and without (grey) market interaction; the left panel shows the treatments without and the right panel for those with SC information. For the treatments without SC information, the average risk premium hovers around zero for both the market and the nonmarket treatment. For the treatments with SC information, the average risk premium again is around zero for the nonmarket treatment but becomes larger over time for the market treatment. There seems to be no difference between the market and nonmarket setting without SC information, while with SC information participants seem less willing to take risks in the market setting. While risk premia are around zero in all treatments except the market treatment with SC information, both assets are priced substantially below their expected value of 100 (Table 4 in Appendix G) indicating risk aversion in all treatments.

In order to assess statistical significance of the treatment effects on risk premia, we ran a random-effects OLS regression estimating the following equation:

$$
R P_{j}^{t}=\alpha+\beta_{1} \times \text { Market }+\beta_{2} \times \operatorname{SCinfo}+\beta_{3} \times \text { SCinfo } \times \text { Market }+\eta_{j}+\epsilon_{j}^{t}
$$

where $R P_{j}^{t}$ refers to the risk premium of group $j$ in period $t$, Market is a dummy for the market treatments and SCinfo a dummy for the presence of social comparison information. Table 1 presents the results. Of particular interest are the coefficients $\beta_{1}$ measuring the impact of market interactions in the absence of SC information and the coefficient $\beta_{1}+\beta_{3}$ measuring the impact of market interactions with SC information.

Market interaction decreases the willingness to take risks if and only if there is SC information. While $\beta_{1}$ is small, changing in sign and statistically not significant, the coefficient $\beta_{1}+\beta_{3}$ is substantial and growing 


\begin{tabular}{lcccc}
\hline & $(1)$ & $(2)$ & $(3)$ & $(4)$ \\
& All & $6-10$ & $16-20$ & $26-30$ \\
\hline Constant $(\alpha)$ & 1.042 & 1.974 & 1.995 & 2.034 \\
Market $\left(\beta_{1}\right)$ & $(2.094)$ & $(3.960)$ & $(4.166)$ & $(3.590)$ \\
SCinfo $\left(\beta_{2}\right)$ & 0.008 & -0.801 & -3.401 & -1.642 \\
& $(3.121)$ & $(4.494)$ & $(6.327)$ & $(3.516)$ \\
SCinfo $\times$ Market $\left(\beta_{3}\right)$ & -1.982 & -0.465 & -1.033 & -3.480 \\
& $(1.617)$ & $(6.894)$ & $(5.289)$ & $(4.241)$ \\
\hline$\beta_{1}+\beta_{3}$ & $(3.151)$ & $(9.340)$ & $(8.393)$ & $(4.028)$ \\
$p$-value test $\beta_{1}+\beta_{3}=0$ & $6.564^{*}$ & 3.379 & 4.313 & $11.448^{* *}$ \\
$\beta_{2}+\beta_{3}$ & 0.073 & 0.590 & 0.548 & 0.044 \\
$p$-value test $\beta_{2}+\beta_{3}=0$ & 4.574 & 3.733 & 6.681 & $9.610^{*}$ \\
\hline Observations & 0.195 & 0.526 & 0.147 & 0.063 \\
Number of groups & 880 & 152 & 152 & 152 \\
\hline & 32 & 32 & 32 & 32 \\
\hline & Robust standard errors in parentheses & \\
$*$ & $<0.01,{ }^{* *} p<0.05,{ }^{*} p<0.1$ & \\
\end{tabular}

Table 1: Difference in risk premium between treatments. Column (1) shows all data, Columns (2)-(4) focus on mature behavior in the second half of each of the three repetitions, i.e. rounds 6-10, 16-20 and 26-30. Note that the number of observations is smaller than $960\left(32^{*} 30\right)$ or $160\left(32^{*} 5\right)$, respectively. The reason is that in some periods there was no trade for at least one of the assets. In these cases the market price for that asset and the risk premium are set to missing.

over time. Across the last 5 periods the risk premium in "transparent markets" is more than 11 tokens higher, a more than 500\% increase over the corresponding nonmarket setting (Column (4) in Table 1). Despite the fact that excessive risk-taking with all its consequences occurs frequently in markets, we find that markets are not causal to such behaviour. By contrast, markets even reduce risk in the presence of social comparison information, suggesting that markets may not be the worst institution to discipline excessive risk-taking.

Further analysis and robustness checks reveal that the effect is stronger if the initial distribution of signals seems favorable to the less risky asset for a greater number of participants (Table 5 in Appendix G). Controlling for participants' personality and demographic characteristics elicited in a post-experimental questionnaire does not affect the estimated coefficient size $\beta_{1}+\beta_{3}$ substantially. Effect sizes tend to be even bigger and statistical significance improves once these controls are included (Table 8 in Appendix G). Finally, we also analyzed time trends and did not find statistically significant time trends within treatments (Table 7 in Appendix G). Results are also robust when considering an alternative implementation of the nonmarket condition described in Appendix I.

The coefficient $\beta_{2}+\beta_{3}$ shows the effect of adding social comparison information to markets. This coefficient being positive indicates that increasing transparency in markets disciplines risk-seeking behaviour. The statistical significance of this effect is only marginal in Table 1, but increases as individual characteristics of market participants are controlled for (see Table 8 in Appendix G).

\section{Discussion}

Why does market interaction decrease participants' willingness to take risks? In this section we show how social comparison preferences can increase risk premia in markets. We then discuss alternative mechanisms. 
The fact that markets decrease willingness to take risks if and only if social comparison information is provided suggests that the latter plays an important role in explaining the effect of markets on risk-taking behaviour. Social comparison information will matter, for example, if people have social reference points, i.e. if they evaluate their outcomes relative to the outcomes of others. In fact, there is a solid body of evidence demonstrating loss aversion with respect to social reference points (Vendrik and Woltjer, 2007; Kuhn et al., 2011; Linde and Sonnemans, 2012). It can be shown that if participants have reference dependent preferences with respect to a social reference point, then our markets will induce higher risk premia whenever social comparison information is provided. The correlation structure of risk plays an important role for this effect. To see this note that when a given asset is traded, risk is negatively correlated: what one side of the market gains, the other side loses. One implication of such negative correlation is that risk premia in the market condition are increasing in the extent to which social comparison utility matters to individuals.

We establish this point more formally by building on the model of reference dependent preferences developed by Kőszegi and Rabin (2006). Following Schmidt et al. (2015), we then incorporate a social comparison reference point into the model. Consider an agent $i$ facing a lottery with $K$ outcomes $x_{k}$ and associated probabilities $p_{k}(k=1, \ldots, K)$. We denote by $r_{\ell}(\ell=1, \ldots, L)$ the agent's social comparison reference point and consider a probability distribution $p_{k \ell}$ over pairs $\left(x_{k}, r_{\ell}\right)$. Let the agent's utility $V$ be given by

$$
V=\eta\left[\sum_{k} p_{k} u\left(x_{k}\right)\right]+\psi\left[\sum_{k, \ell} p_{k \ell} v\left(u\left(x_{k}\right)-u\left(r_{\ell}\right)\right)\right] .
$$

The term in the first pair of squared brackets is the expected (consumption) utility of the gamble (asset) held, where we assume $u$ to be concave. The parameter $\eta$ is the weight on consumption utility and $\psi$ captures the weight on gain-loss or social comparison utility. Following Köszegi and Rabin (2006), we assume that $v$ is continuous, strictly increasing and steeper for losses than for gains. In our market setting with five agents, two assets and each agent possibly holding multiple units of each assets, the space of possible pairs $\left(x_{k}, r_{\ell}\right)$ (as well as the number of possible definitions of $r_{\ell}$ ) is quite big. Though, in order to understand how social comparison affects the risk premium in markets it suffices to consider a simple trade between two agents $i$ and $j$ where the high risk asset (HR) is swapped for the low-risk asset (LR). Assume that $i$ 's social comparison reference point is $j$ 's outcome $x$ and vice versa. Under these assumptions it can be shown that the risk premium defined as $V_{i}^{L R}-V_{i}^{H R}$ is increasing in $\psi$ (Appendix F).

In other words, in markets where trades make outcomes negatively correlated, the risk premium will increase in the extent to which participants care about social comparison. In the nonmarket treatments, where risks are idiosyncratic, social comparison information should not affect risk premia, which is consistent with our evidence (Schmidt et al., 2015). Consistently with this social comparison explanation, we also find that participants are less eager to hold assets at all: Both assets are priced lower with market interactions (Table 6 in Appendix G). At this point it should be noted that not any trade in markets implies negative correlation of risk. Depending on their portfolio, market participants can swap different assets to reduce risk for both (Gortner and van der Weele, 2015). In our setting, however, this is not possible. Any trade of a given asset does necessarily involve negative correlation.

Some other possible mechanisms seem worth pointing out. First, reference-dependent preferences with probability weighting (Tversky and Kahneman, 1992) have been linked with a preference for positively skewed securities (Barberis and Huang, 2008). Such a mechanism, however, cannot explain any of our treatment differences, because it should operate in the same way in the market and nonmarket condition and with and without social comparison information. Second, while in the BDM the distribution of prices 
is uniform, in the market this is typically not the case. This differences in the distributions of prices could lead traders to be perceived as more risk averse in the market setting under non-expected utility theory (Machina, 1982). However, we study risk premia comparing high and low risk assets and it is not clear why they should be affected by this difference. Moreover, we find that markets lead to increased risk aversion if and only if social comparison information is provided; distributional differences alone cannot account for this effect.

\section{Conclusions}

We investigated whether markets induce risk taking behaviour. We isolate the effects of market interaction keeping other possibly confounding factors constant. Somewhat surprisingly, we found that markets decrease participants' willingness to take risks. This is the case, however, if and only if information about the outcomes of other market participants is provided. In the absence of such social comparison information, risk premia in markets do not differ from those in the non-market settings. Our findings can be explained by social comparison utility in the presence of negatively correlated risks.

It is important to note that our results do not question the fact that frequently we do observe excessive risk-taking in markets. There is ample evidence demonstrating that this can indeed be the case. What they do question, however, is whether market interaction is causal to such risk taking. Our results suggest that it is other factors, such as specific aspects of remuneration packages, bonuses paid to financial traders, self-selection into trading or individual factors (see e.g. Kuhnen and Knutson (2005); Porcelli and Delgado (2009); Coates et al. (2009)) that cause excessive risk taking in financial markets. Evidence from our post experimental questionnaire gives some clues into which individual factors affect pricing. Risk premia are higher if market participants are more risk averse or have higher cognitive ability and they are lower if participants are male, more optimistic, conscientious or neurotic according to measures elicited in the questionnaire (Table 8 in Appendix G). Market interaction, by contrast, tends to mitigate excessive risktaking rather than exacerbate it at least in our setting. We cannot rule out that in other market settings (e.g. with a different correlation structure of risk), different effects will be observed. Our results do show, however, that there is no general tendency for markets to induce risk-taking behaviour.

Our results suggest some possibilities to harness social comparison effects to discourage excessive risk taking. In some online platforms (zulutrade.com; etoro.com), for example, individual investors can observe outcomes of other market participants and can even decide to mimic their strategies. In other markets, by contrast, there is only limited transparency and if at all outcomes of only few market participants can be observed. Since, adding social comparison information increases risk premia, this could be one channel why less risky behaviour is observed in exchanges compared to OTC or such dark pool markets. Our results hence contribute to the debate around recent legislation (Dodd-Frank Act in the U.S. and the "Markets in Financial Instruments Directive (MiFID II)" in the EU) that aims at providing transparency to dark pools, or even disallowing them altogether. Future research should study how robust our findings are and if there are interaction effects when different institutional details are considered. Future experiments could vary the number and correlation structure of assets, the shape of information flows, how traders are remunerated, etc. 


\section{References}

Aldrich, E. and A. Gallant (2011). Habit, long-run risk, prospect? Journal of Financial Econometrics 9(4), 589-618.

Barberis, N. and M. Huang (2008). Stocks as lotteries: The implications of probability weighting for security prices. American Economic Review 98(5), 2066-2100.

Bartling, B., R. Weber, and L. Yao (2015). Do markets erode social responsibility? Quarterly Journal of Economics 130(1), 219-266.

Becker, G., M. DeGroot, and J. Marschak (1964). Measuring utility by a single-response sequential method. Behavioral Science 9(3), 226-232.

Bernanke, B. (2008). Reducing system risk. In Speech at the Federal Reserve Bank of Kansas City's Annual Economic Symposium.

Bohm, P., J. Linden, and J. Sonnegard (1997). Eliciting reservation prices: Becker-DeGroot-Marschak mechanisms vs markets. Economic Journal 10\%, 1079-1089.

Bursztyn, L., F. Ederer, B. Ferman, and N. Yuchtman (2014). Understanding mechanisms underlying peer effects: Evidence from a field experiment on financial decisions. Econometrica 82(4), 1273-1301.

Campbell, J. and J. Cochrane (1999). By force of habit: A consumption-based explanation of aggregate stock market behavior. The Journal of Political Economy 107, 205-251.

Coates, J., M. Gurnell, and A. Rustichini (2009). Second-to-fourth digit ratio predicts success among highfrequency financial traders. Proceedings of the National Academy of Sciences of the United States of America 106(2), 623-628.

Dong, Z., C. Wang, and F. Xie (2010). Do executive stock options induce excessive risk taking? Journal of Banking and Finance 34(10), 2518-2529.

Falk, A. and N. Szech (2013). Morals and markets. Science 340(3), 707-711.

Fischbacher, U. (2007). z-tree: Zurich toolbox for ready-made economic experiments. Experimental Economics 10(2), 171-178.

Gortner, P. and J. van der Weele (2015). Peer effects and risk sharing in experimental asset markets. mimeo.

Greiner, B. (2004). An online recruitment system for economic experiments. In K. Kremer and V. Macho (Eds.), Forschung und wissenschaftliches Rechnen. GDWG Bericht 63.

Hayek, F. (1945). The use of knowledge in society. American Economic Review 35(4), 519-530.

Hong, H., J. Kubik, and J. Stein (2005). Thy neighbor's portfolio: Word-of-mouth effects in the holdings and trades of money managers. Journal of Finance 60, 2801-2824.

Karni, E. and Z. Safra (1987). Preference reversal and the observability of preferences by experimental methods. Econometrica 55(3), 675-685. 
Köszegi, B. and M. Rabin (2006). A model of reference dependent preferences. Quarterly Journal of Economics 121, 1133-1165.

Kuhn, P., P. Kooreman, A. Soetevent, and A. Kapteyn (2011). The effects of lottery prizes on winners and their neighbours: Evidence from the Dutch postcode lottery. American Economic Review 101(5), $2226-2247$.

Kuhnen, C. and B. Knutson (2005). The neural basis of financial risk taking. Neuron 47(5), 763-770.

Linde, J. and J. Sonnemans (2012). Social comparison and risky choices. Journal of Risk and Uncertainty 44, $45-72$.

Machina, M. (1982). Expected utility analysis without the independence axiom. Econometrica 50(2), $277-323$.

Matutes, C. and X. Vives (2000). Imperfect competition, risk taking and regulation in banking. European Economic Review 44(1), 1-34.

North, M. (1991). Institutions. Journal of Economic Perspectives 5(1), 97-112.

Oechssler, J., J. Schmidt, and W. Schnedler (2011). On the ingredients for bubble formation: Informed traders and communication. Journal of Economic Dynamics and Control 35, 1831-1851.

Plott, C. and V. Smith (2008). Handbook of Experimental Economic Results. Elsevier.

Porcelli, A. and M. Delgado (2009). Acute stress modulates risk taking in financial decision making. Psychological Science 20(3), 278-283.

Reinhart, C. and K. Rogoff (2009). This time is different-Eight centuries of financial folly. Princeton University Press.

Schmidt, U., A. Friedl, and K. L. de Miranda (2015). Social comparison and gender differences in risk taking. mimeo.

Schoenberg, J. and E. Haruvy (2012). Relative performance information in asset markets: an experimental approach. Journal of Economic Psychology 33(6), 1143-1155.

Shleifer, A. (2004). Does competition destroy ethical behavior? American Economic Review Papers and Proceedings 94(2), 414-418.

Tversky, A. and D. Kahneman (1992). Advances in prospect theory: Cumulative representation of uncertainty. Journal of Risk and Uncertainty 5(4), 297-323.

Vendrik, M. and G. Woltjer (2007). Happiness and loss aversion: Is utility concave or convex in relative income? Journal of Public Economics 91, 1423-1448.

Wachter, J. (2006). A consumption-based model of the term structure of interest rates. Journal of Financial Economics 79, 365-399. 


\section{A Design Details and Procedures}

Parameter settings Table 2 presents the parameter settings for the different matching groups in the different repetitions. In all matching groups the left (right) asset was referred to as the red (green) asset in the first repetition, as the yellow (purple) asset in the second repetition and as the blue (orange) asset in the third repetition. Across matching groups and repetitions there was variation in whether the left or the right asset was the more or less risky one. Moreover, the distribution of signals differed across matching groups and repetitions. We adopted two different distributions of signals: In distribution $\rho_{1}\left(\rho_{2}\right)$ three individuals receive a signal that the more (less) risky asset is marginally better, one that the less (more) risky asset is marginally better, and one that the less (more) risky asset is way better.

For instance, in matching group 3 and repetition 2 the left (yellow) asset was less risky than the right (purple) asset and the signal distribution was in accordance to distribution $\rho_{1}$ with individuals 1,2 and 4 receiving a signal that the more risky asset is marginally better, individual 3 that the less risky asset is marginally better, and individual 5 that the less risky asset is way better.

\begin{tabular}{|c|c|c|c|c|c|c|c|c|c|c|c|c|}
\hline \multirow{2}{*}{$\begin{array}{l}\text { Matching group } \\
\text { Repetition }\end{array}$} & \multicolumn{3}{|c|}{$1-2$} & \multicolumn{3}{|c|}{$3-4$} & \multicolumn{3}{|c|}{$5-6$} & \multicolumn{3}{|c|}{$7-8$} \\
\hline & 1 & 2 & 3 & 1 & 2 & 3 & 1 & 2 & 3 & 1 & 2 & 3 \\
\hline $\begin{array}{l}\text { Color asset } \mathrm{L} \\
\text { Color asset } \mathrm{R}\end{array}$ & $\begin{array}{l}\text { red } \\
\text { green }\end{array}$ & $\begin{array}{l}\text { yellow } \\
\text { purple }\end{array}$ & $\begin{array}{l}\text { blue } \\
\text { orange }\end{array}$ & $\begin{array}{l}\text { red } \\
\text { green }\end{array}$ & $\begin{array}{l}\text { yellow } \\
\text { purple }\end{array}$ & $\begin{array}{l}\text { blue } \\
\text { orange }\end{array}$ & $\begin{array}{l}\text { red } \\
\text { green }\end{array}$ & $\begin{array}{l}\text { yellow } \\
\text { purple }\end{array}$ & $\begin{array}{l}\text { blue } \\
\text { orange }\end{array}$ & $\begin{array}{l}\text { red } \\
\text { green }\end{array}$ & $\begin{array}{l}\text { yellow } \\
\text { purple }\end{array}$ & $\begin{array}{l}\text { blue } \\
\text { orange }\end{array}$ \\
\hline Return L [1] & 50 & 50 & 50 & 50 & 50 & 50 & 50 & 50 & 50 & 50 & 50 & 50 \\
\hline Return L [2] & 100 & 50 & 50 & 50 & 100 & 100 & 100 & 50 & 100 & 50 & 100 & 50 \\
\hline Return L [3] & 100 & 100 & 100 & 100 & 100 & 100 & 100 & 100 & 100 & 100 & 100 & 100 \\
\hline Return L [4] & 100 & 150 & 150 & 150 & 100 & 100 & 100 & 150 & 100 & 150 & 100 & 150 \\
\hline Return L [5] & 150 & 150 & 150 & 150 & 150 & 150 & 150 & 150 & 150 & 150 & 150 & 150 \\
\hline Return R [1] & 50 & 50 & 50 & 50 & 50 & 50 & 50 & 50 & 50 & 50 & 50 & 50 \\
\hline Return R [2] & 50 & 100 & 100 & 100 & 50 & 50 & 50 & 100 & 50 & 100 & 50 & 100 \\
\hline Return R [3] & 100 & 100 & 100 & 100 & 100 & 100 & 100 & 100 & 100 & 100 & 100 & 100 \\
\hline Return R [4] & 150 & 100 & 100 & 100 & 150 & 150 & 150 & 100 & 150 & 100 & 150 & 100 \\
\hline Return R [5] & 150 & 150 & 150 & 150 & 150 & 150 & 150 & 150 & 150 & 150 & 150 & 150 \\
\hline Signal L [1] & 100 & 150 & 50 & 100 & 100 & 100 & 100 & 50 & 50 & 150 & 100 & 150 \\
\hline Signal L [2] & 50 & 150 & 150 & 50 & 50 & 100 & 50 & 150 & 100 & 100 & 150 & 50 \\
\hline Signal L [3] & 100 & 50 & 100 & 150 & 100 & 50 & 150 & 50 & 100 & 150 & 100 & 150 \\
\hline Signal L [4] & 100 & 50 & 50 & 50 & 100 & 150 & 100 & 150 & 150 & 50 & 100 & 100 \\
\hline Signal L [5] & 150 & 100 & 150 & 150 & 150 & 100 & 100 & 100 & 100 & 50 & 50 & 50 \\
\hline Signal R [1] & 150 & 50 & 150 & 50 & 150 & 50 & 50 & 100 & 150 & 50 & 150 & 100 \\
\hline Signal R [2] & 100 & 100 & 100 & 100 & 100 & 50 & 150 & 100 & 150 & 150 & 100 & 150 \\
\hline Signal R [3] & 50 & 100 & 50 & 100 & 50 & 150 & 100 & 150 & 50 & 100 & 50 & 100 \\
\hline Signal R [4] & 150 & 100 & 100 & 150 & 150 & 100 & 150 & 100 & 100 & 100 & 50 & 50 \\
\hline Signal R [5] & 50 & 150 & 100 & 100 & 50 & 150 & 50 & 50 & 50 & 100 & 150 & 100 \\
\hline Distribution & $\rho_{1}$ & $\rho_{2}$ & $\rho_{1}$ & $\rho_{1}$ & $\rho_{1}$ & $\rho_{2}$ & $\rho_{2}$ & $\rho_{1}$ & $\rho_{2}$ & $\rho_{2}$ & $\rho_{2}$ & $\rho_{1}$ \\
\hline
\end{tabular}

Table 2: Parameter settings.

Strategic manipulation There is not much evidence of strategic manipulation in experimental double auction markets even in settings that were designed to encourage such manipulation (Veiga and Vorsatz, 2009). Our setting is less conducive to strategic manipulation, because there are no informational asymmetries. Hence, none of the participants should feel that they have an informational advantage they could potentially capitalize on. Finally, even if some participants did try to attempt to manipulate prices, it is not clear how this should differentially affect the more and less risky assets and hence the risk premium.

Sources of financial support The payments to the participants in the experiments were covered by the private research budget provided by the departments of the authors. Both authors were partly supported by personal research grants from the Dutch Science Foundation (NWO Veni and Vidi grants). 
Ethical approval The experiments were conducted at the BEElab, the experimental laboratory of the School of Business and Economics of Maastricht University (where both authors were affiliated at the time the experiment was conducted). Experiments can only be conducted at the BEElab after the design and procedures have been presented at a "proposal meeting" and subsequently have found approval of the labmanager and the other lab-members present at the meeting. This internal approval process, that screens in accordance to the ruling international standards of economic experiments, replaces an official IRB approval (which is to date rather uncommon in the Netherlands). 


\section{B Sample Instructions (Market-SCinfo)}

Welcome and thanks for participating in this experiment. Please, read these instructions carefully. They are identical for all the participants with whom you will interact during this experiment. If you have a question, please, raise your hand. One of the experimenters will come to you and answer your questions. From now on communication with other participants is not allowed. If you do not conform to these rules we are sorry to have to exclude you from the experiment. Please do also switch off your mobile phone at this moment. At the end of the experiment you will receive a payment. How much you get depends on your decisions and those of other participants. During the experiment the earnings are expressed in ECU (Experimental Currency Units). At the end of the experiment the ECUs collected are converted into Euros according to the exchange rate $1 \mathrm{ECU}=5$ Eurocents. In addition there is the 5 Euro show up fee. All your decisions will be treated confidentially.

\section{The experiment}

There will be two different assets in this experiment, which will be labeled with different colors. In these instructions we will talk about the BLACK asset and the WHITE asset. In the experiment, however, different colors will be used.

Both assets have one of the following three possible returns: 50 ECU, 100 ECU or 150 ECU. The difference between the two assets is the probabilities with which these possible returns realize. In other words the chance to get 50 or 100 or 150 is different for the BLACK compared to the WHITE asset. The only thing you know is that each of these returns is possible with positive probability for both assets.

One way to think about this is that both the BLACK and the WHITE asset represent an envelope with money containing bills of 50 ECU, 100 ECU and 150 ECU. The difference is that the BLACK and WHITE envelope might contain different numbers of each of these bills. The only thing you know is that in each envelope there is at least one bill of each kind.

In total the experiment consists of three repetitions. In each repetition there will be different assets. You can trade assets in each repetition for ten trading periods.

\section{Signal}

At the beginning of each repetition you receive a signal. A signal is a piece of information for you about each of the assets. You will receive the following signal. For each asset we will tell you one number 50, 100 or 150. The probability with which we tell you each of these numbers corresponds to the probability with which the asset has this return. Hence the higher the probability that the asset has a certain return, the higher the chance that we show you this number.

In terms of our envelope example you can think about your signal as follows. We randomly draw one bill out of each envelope and show it to you. Hence the more bills of a certain type an envelope contains, the more likely it is that we draw one of these.

In the experiment you will be matched with four other participants in a group. Not only you, but also all of the other group members will receive a signal in the same manner as you. Note, however, that different participants might receive different signals. 


\section{The trading}

In each trading period, you have one share of each asset (BLACK and WHITE) in stock. You will tell us two numbers:

(i) your buying price: this is the maximum price at which you are willing to buy one more share of this asset, and

(ii) your selling price: this is the minimum price at which you are willing to sell your share of this asset.

Hence, in total you will tell us four numbers, two for each asset.

All group members will tell us their four numbers simultaneously. Afterwards, for each asset BLACK and WHITE, the buying prices of all group members are ranked highest to lowest and the selling prices of all group members are ranked lowest to highest.

The market price of each asset is determined as follows:

1. First we compare the lowest selling price with the highest buying price.

- If this selling price is higher than this buying price, then there is no market price (which we will mark with $\mathrm{xxx}$ ).

- Otherwise, we proceed to 2.

2. Compare the second-lowest selling price with the second-highest buying price.

- If this selling price is higher than this buying price, then the market price is the average of the lowest selling price and the highest buying price.

- Otherwise, we proceed with 3.

3. Compare the third-lowest selling price with the third-highest buying price.

- If this selling price is higher than this buying price, then the market price is the average of the second-lowest selling price and the second-highest buying price.

- Otherwise, we proceed to 4.

4. Compare the fourth-lowest selling price with the fourth-highest buying price.

- If this selling price is higher than this buying price, then the market price is the average of the third-lowest selling price and the third-highest buying price.

- Otherwise, we proceed to 5 .

5. Compare the fifth-lowest (or highest) selling price with the fifth-highest (or lowest) buying price.

- If this selling price is higher than this buying price, then the market price is the average of the fourth-lowest selling price and the fourth-highest buying price.

- Otherwise, the market price is the average of this fifth-lowest selling price and this fifth-highest buying price. 
For example, assume that, for some asset, the five buying prices are $(5400,100,21,7,1)$ and the selling prices are $(8,24,65,201,300)$. The lowest selling price of 8 is lower than the highest buying price of 5400 . Hence, we proceed to step 2. The second-lowest selling price of 24 is lower than the second-highest buying price of 100. Hence, we proceed to step 3. The third-lowest selling price of 65 is higher than the third-highest buying price of 21 . Hence, two shares are traded in your group and the market price is the average between the second-lowest selling price of 24 and the second-highest buying price of 100, which is 62 .

Once the market price is determined, all group members with buying prices above the market price and with selling prices below the market price will trade one share of the asset (at the market price). In case there is excess demand or excess supply, group members with higher buying prices and lower selling prices will trade first. In case of ties (equal buying prices or equal selling prices) between group members, a random selection of these will be trading.

\section{Information}

At the end of each period you will observe for each asset (BLACK and WHITE):

- the market price;

- the buying and selling prices of all group members;

- whether you sold the asset, you bought the asset, or did not make any trade at all.

\section{Your earnings in the experiment}

At the end of the experiment one period is randomly drawn. Your earnings in the experiment are based on your payoff from that randomly drawn period.

First the return of the BLACK and the WHITE asset (either 50, 100 or 150) are determined according to the respective probabilities. In terms of our envelope example you can think of one bill being randomly drawn from the BLACK and one from the WHITE envelope.

Your payoff in this period is then computed as follows:

$$
\begin{aligned}
\text { Payoff }= & \text { Number of shares of BLACK asset } \times \text { Return of BLACK asset } \\
& + \text { Number of shares of WHITE asset } \times \text { Return of WHITE asset } \\
& - \text { Market price BLACK asset if a share of this asset is bought } \\
& + \text { Market price BLACK asset if a share of this asset is sold } \\
& - \text { Market price WHITE asset if a share of this asset is bought } \\
& + \text { Market price WHITE asset if a share of this asset is sold }
\end{aligned}
$$

\section{Questionnaire}

At the end of the experiment there will be a short questionnaire for you to fill in.

If you have any questions about these instructions or the experiment, then please raise your hand now and someone will come and answer them. Once everyone has finished reading the instructions some control questions will appear on your screen that will allow you to test your understanding of the instructions. 


\section{Screenshots (Market-SCinfo)}

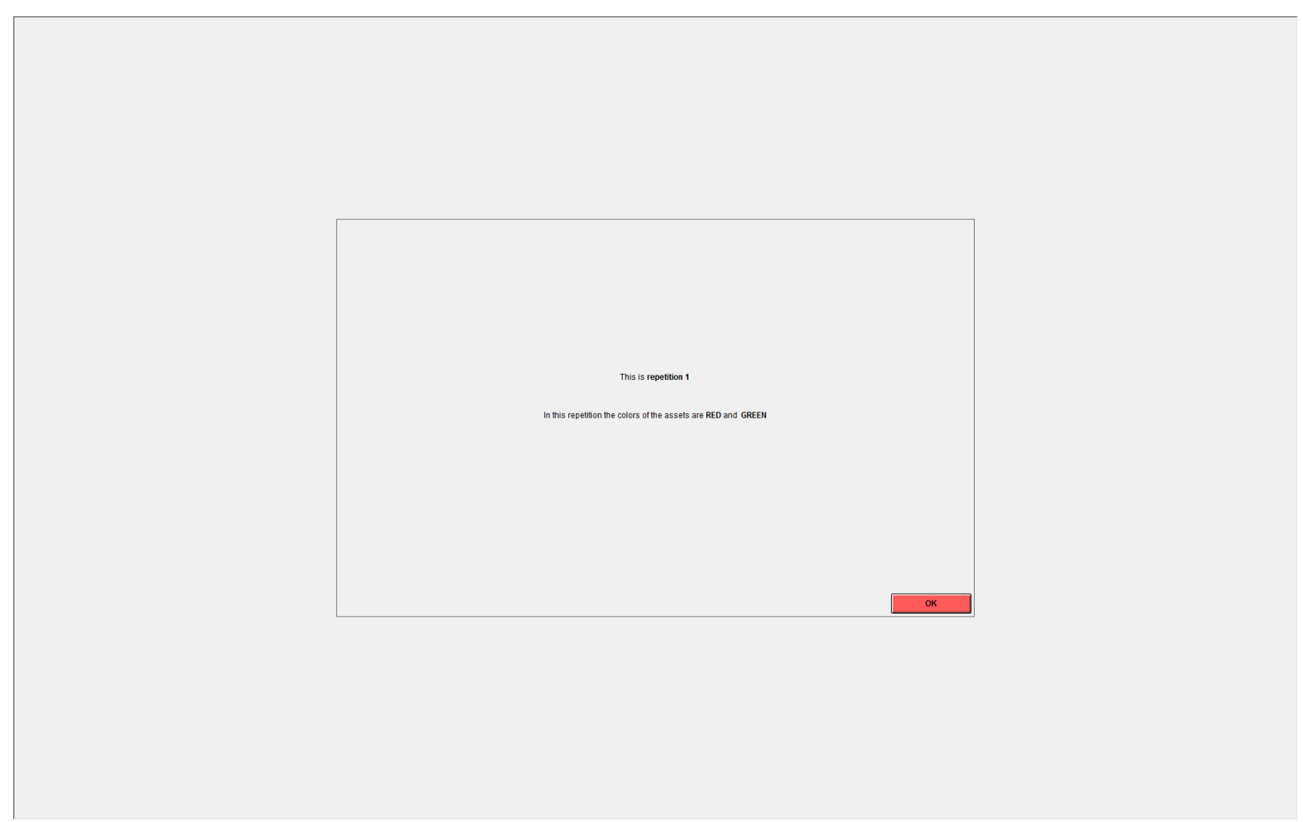

Figure 2: Start of a new repetition. Before each sequence of ten trading periods, participants get notified via this screen that a new repetition of ten trading periods starts. Across repetitions, color-names of assets, the realization probabilities of the possible return values, and the signals are different (see Table 2); within repetitions these are constant.

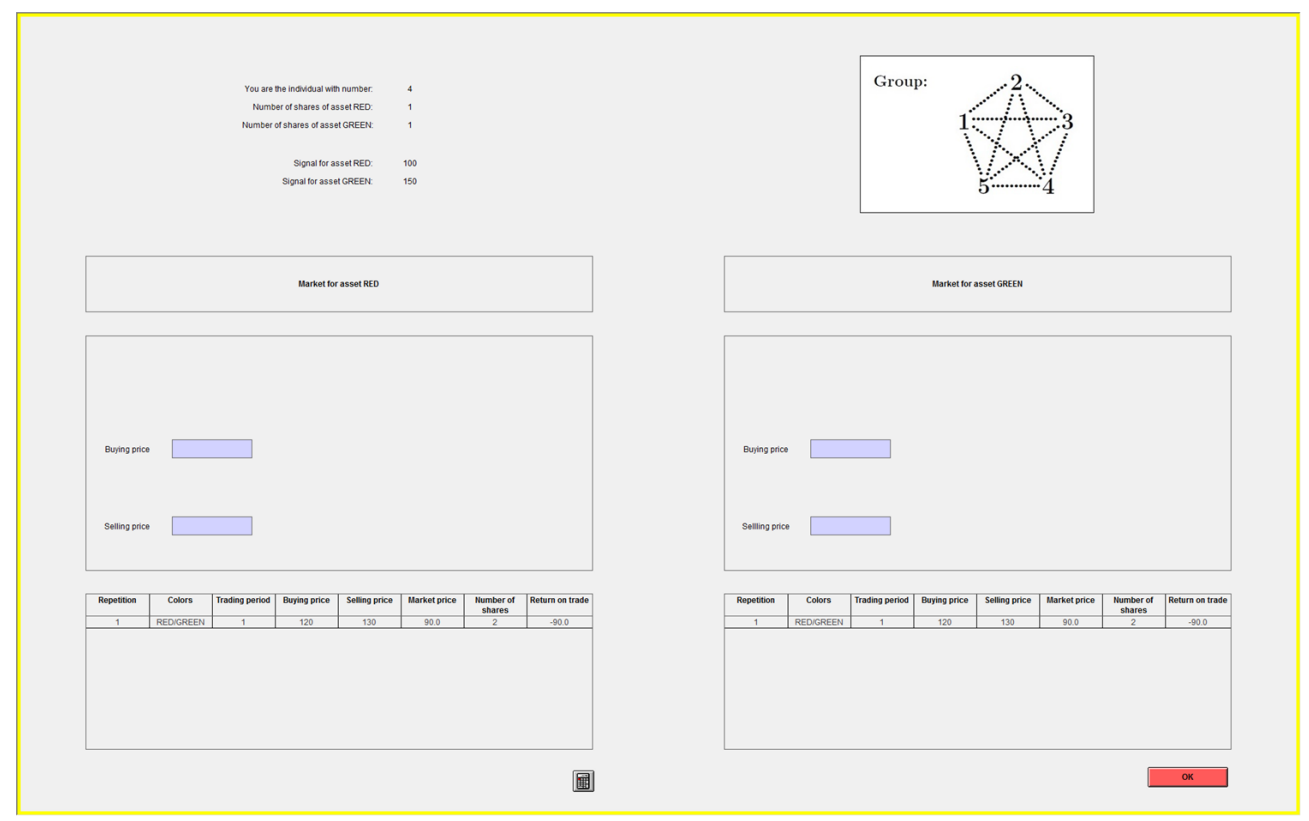

Figure 3: Decision screen. At the upper-left part of the screen, individuals are notified on their identity within the group (where the figure at the upper-right shows the group; dashed line are not present in the treatments without SC information), the number of shares of each asset in stock (which equals 1 at the beginning of each trading period), and the signals they obtained for each asset. In the middle part, participants enter their buying and selling prices for each of the assets; values between 50 and 150 needs to be entered, with buying prices not being above the selling prices. At the bottom of the screen there are history boxes storing important feedback on what happened before in the markets for the right and left asset. 




Figure 4: Feedback screen. The upper part of the screen is organized similar as in the decision screen. The middle part contains information on all individuals their buying and asking prices (in the treatment without SC information only information on own buying and selling prices are contained). The bottom part reports important feedback on the consequences of the decisions in the markets for the right and left asset, such as: the market price, the number of shares traded, whether you bought another share or sold the one you had in stock, the number of shares left after trade, and the return on trade (which is negative in case an asset is bought and positive in case an asset is sold). In the nonmarket treatments, the market price is labeled "group value" and in addition the randomly drawn price at which exchange takes place is presented. The returns of the assets are not learnt until the very end of the session.

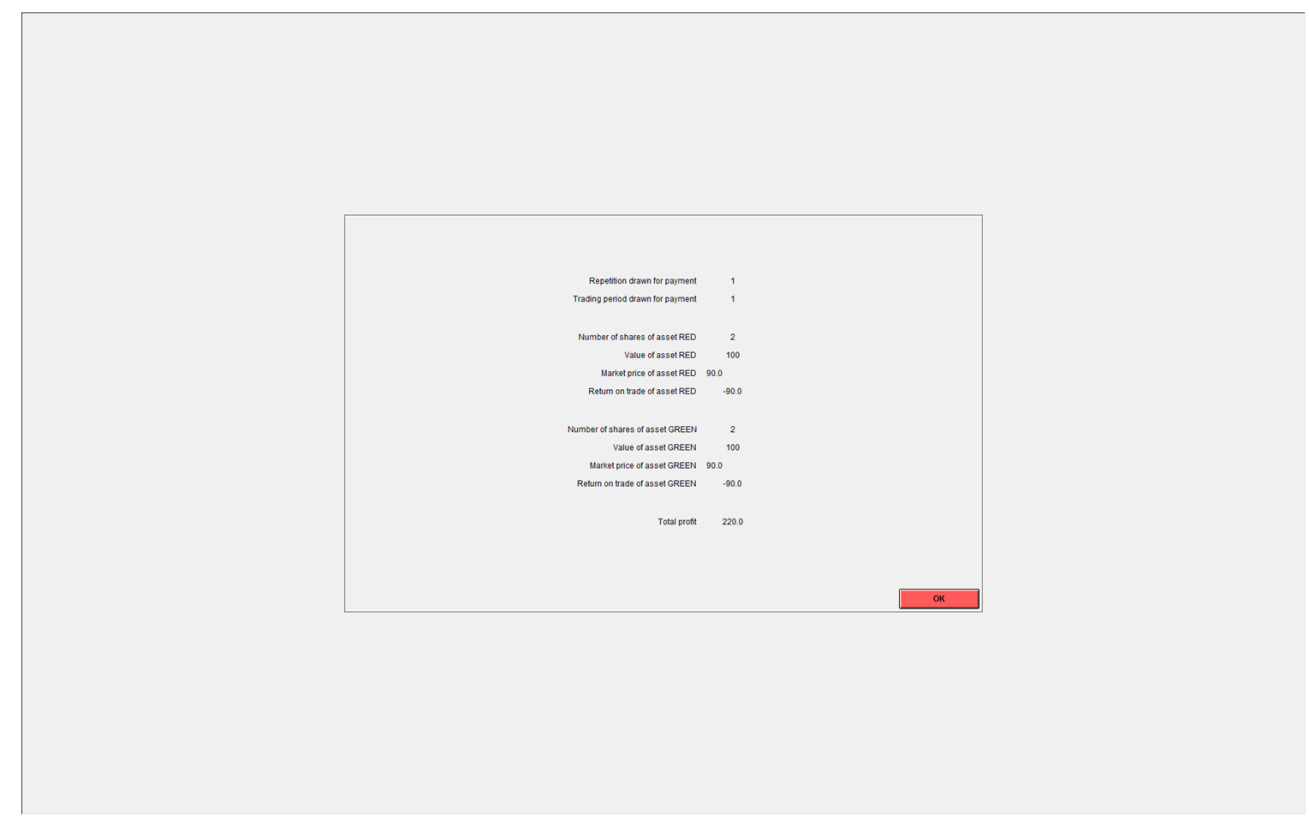

Figure 5: Screen with final payment information. Participants are informed which repetition and trading period are selected for final payment. For each of the assets, participants see how many shares they had after trade and what they paid for buying another share or selling their share (or 0 if neither of the two happened) in that respective repetition and trading period. Finally, the participants learn the value (return) of the assets. All this information aggregates into a final payoff, that is presented (in ECU and excluding show-up fee) on the last line. 


\section{Post-experimental Questionnaire}

Cognitive ability For the cognition task, we used the symbol-digit correspondence test from the Wechsler Adult Intelligence Scale (WAIS), in which subjects had 90 seconds to find as many correspondences between symbols and numbers as they could, using the correct number for each symbol (see Figure 6). Speed and accuracy under time pressure determine an individuals ability (Dohmen et al., 2010).

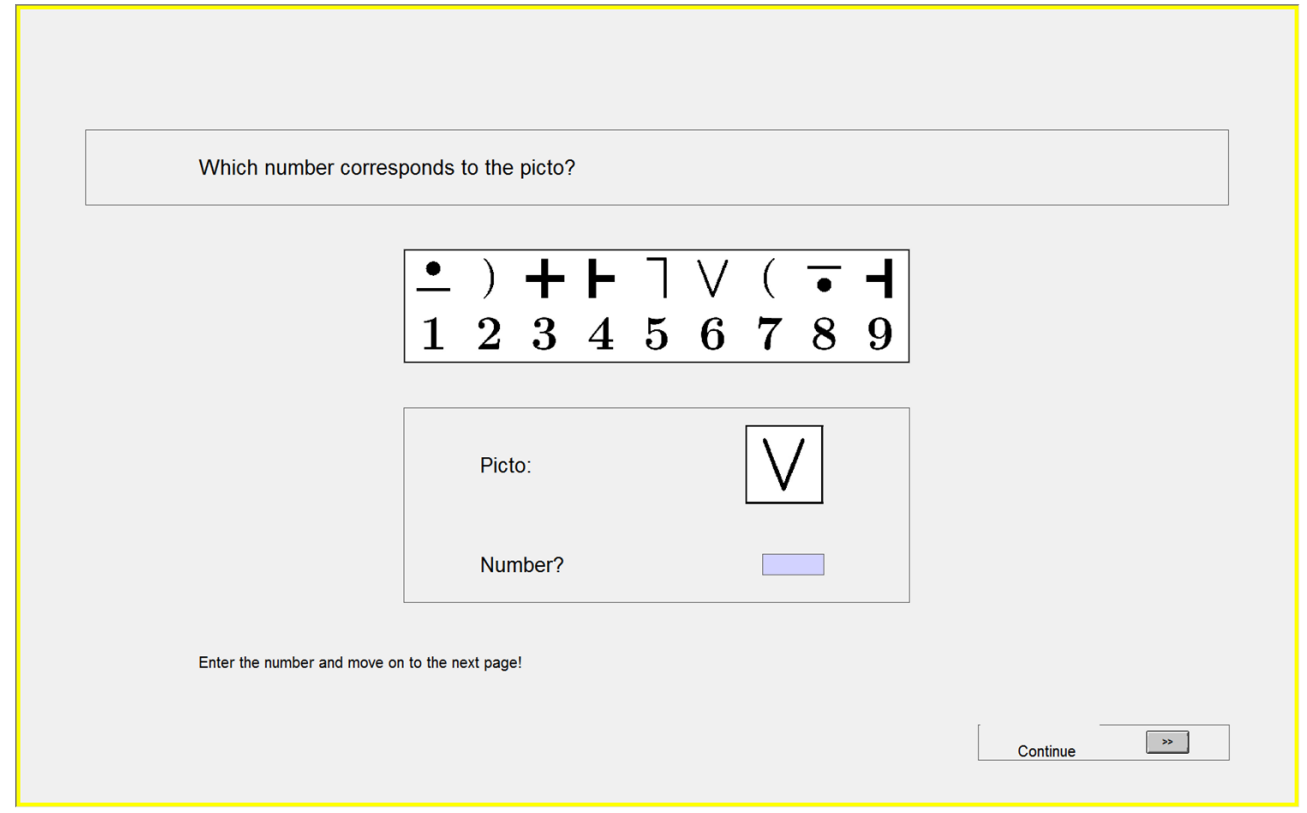

Figure 6: Screenshot of cognitive ability test.

Demographics Participants answered the following questions:

1. What is your age?

2. What is your gender?

3. What is your origin?

4. What are you studying?

5. For how many years in total have you been studying at this or another university?

Risk attitude We elicited risk attitude using the direct approach as suggested in Dohmen et al. (2011). Participants answered the question

How do you see yourself: Are you generally a person who is fully prepared to take risks or do you try to avoid taking risks?

on a ten-point scale running from "Not at all willing to take risks" to "Very willing to take risks".

Machiavellianism The Machiavellianism score was elicited using the Mach-IV test (Christie and Geis, 1970). Participants indicate on a five-point Likert scale (running from "strongly disagree" to "strongly agree") the degree to which they personally agree or disagree with each of the following statements: 
1. Never tell anyone the real reason you did something unless it is useful to do so.

2. The best way to handle people is to tell them what they want to hear.

3. One should take action only when sure it is morally right.

4. Most people are basically good and kind.

5. It is safest to assume that all people have a vicious streak and it will come out when they are given a chance.

6. Honesty is the best policy in all cases.

7. There is no excuse for lying to someone else.

8. Generally speaking, people won't work hard unless they're forced to do so.

9. All in all, it is better to be humble and honest than to be important and dishonest.

10. When you ask someone to do something for you, it is best to give the real reasons for wanting it rather than giving reasons which carry more weight.

11. Most people who get ahead in the world lead clean, moral lives.

12. Anyone who completely trusts anyone else is asking for trouble.

13. The biggest difference between most criminals and other people is that the criminals are stupid enough to get caught.

14. Most people are brave.

15. It is wise to flatter important people.

16. It is possible to be good in all respects.

17. P.T. Barnum was wrong when he said that there's a sucker born every minute.

18. It is hard to get ahead without cutting corners here and there.

19. People suffering from incurable diseases should have the choice of being put painlessly to death.

20. Most people forget more easily the death of their parents than the loss of their property.

Items $3,4,6,7,8,9,10,11,13,14,16$ and 17 are reverse coded.

Competitiveness To assess the participants' desire to win in interpersonal situations, we asked them to indicate on a five-point Likert scale (running from "strongly disagree" to "strongly agree") their belief about themselves concerning the following items:

1. I get satisfaction from competing with others.

2. I am a competitive individual.

3. I will do almost anything to avoid an argument.

4. I try to avoid competing with others.

5. I often remain quiet rather than risk hurting another person.

6. I find competitive situations unpleasant.

7. I try to avoid arguments. 
8. In general, I will go along with the group rather than create conflict.

9. I dont like competing against other people.

10. I dread competing against other people.

11. I enjoy competing against an opponent.

12. I often try to out perform others.

13. I like competition.

14. I dont enjoy challenging others even when I think they are wrong.

Responses to these 14 items aggregate in the Revised Competitiveness Index (Houston et al., 2002). Items 1, 2, 4, 6, 9, 10, 11, 12 and 13 capture the "Enjoyment of Competition"; items 3, 5, 7, 8 and 14 capture "Contentiousness". Items 3-10 and 14 are postulated in reverse.

Optimism To assess participants' degree of optimism we use the Life Orientation Test-Revised (LOT-R) as developed by Scheier et al. (1994). Participants indicated on a five-point Likert scale (running from "strongly disagree" to "strongly agree") their belief about themselves concerning the following items:

1. In uncertain times, I usually expect the best.

2. It's easy for me to relax.

3. If something can go wrong for me, it will.

4. I'm always optimistic about my future.

5. I enjoy my friends a lot.

6. It's important for me to keep busy.

7. I hardly ever expect things to go my way.

8. I don't get upset too easily.

9. I rarely count on good things happening to me.

10. Overall, I expect more good things to happen to me than bad.

Items 3, 7 and 9 are reverse coded; items 2, 5, 6 and 8 are fillers.

Big Five The Big Five covers five broad dimensions of personality: openness, conscientiousness, extraversion, agreeableness, and neuroticism (Costa and McCrae, 1992). Participants indicated on a five-point Likert scale (running from "strongly disagree" to "strongly agree") their belief about themselves concerning the following fifteen items as they are used in the German Socio-Economic Panel:

1. I am someone who does a thorough job.

2. I am someone who is communicative, talkative.

3. I am someone who is somewhat rude to others.

4. I am someone who is original and comes up with new ideas.

5. I am someone who worries a lot.

6. I am someone who has a forgiving nature. 
7. I am someone who tends to be lazy.

8. I am someone who is outgoing, sociable.

9. I am someone who values artistic experiences.

10. I am someone who gets nervous easily.

11. I am someone who does the things effectively and efficiently.

12. I am someone who is reserved.

13. I am someone who is considerate and kind to others.

14. I am someone who has an active imagination.

15. I am someone who is relaxed, handles stress well.

Items 4, 9 and 14 relate to the factor openness; items 1, 7 and 11 to conscientiousness; items 2, 8 and 12 to extraversion; items 3, 6 and 13 to agreeableness; and items 5, 10 and 15 to neuroticism. Items 3, 7, 12 and 15 are stated in reversed form. 


\section{E Sample Information}

In this section we provide some information about our sample. The experiments were conducted at the BEElab at Maastricht University, where the subject pool consists mostly (but not uniquely) of undergraduate students in areas such as law, business, arts and culture and liberal arts degrees. Most students are from either Germany or the Netherlands, but there are also substantial shares of other European countries, as well as a number of Asian, South- and North-American students (see Figure 7).

\begin{tabular}{lcccc}
\hline & Market & Market-SCinfo & NonMarket & NonMarket-SCinfo* \\
\hline Gender (1=male) & 0.425 & 0.550 & 0.375 & 0.400 \\
Age & {$[0,1]$} & {$[0,1]$} & {$[0,1]$} & {$[0,1]$} \\
Risk aversion & 20.525 & 20.9 & 20.825 & 21.700 \\
& {$[18,24]$} & {$[18,25]$} & {$[18,25]$} & {$[18,27]$} \\
Cognitive ability & 3.925 & 3.725 & 4.575 & 4.000 \\
& {$[2,9]$} & {$[1,7]$} & {$[0,9]$} & {$[0,7]$} \\
Machiavellianism & 43.9 & 39.02 & 38.55 & 41.2 \\
& {$[28,57]$} & {$[23,52]$} & {$[25,48]$} & {$[31,53]$} \\
Competitiveness & 60.825 & 59 & 58.975 & 58.15 \\
& {$[48,74]$} & {$[47,76]$} & {$[46,75]$} & {$[38,76]$} \\
Optimism & 45.550 & 46.650 & 47.375 & 46.500 \\
& {$[26,68]$} & {$[29,70]$} & {$[20,70]$} & {$[28,64]$} \\
Openness (B5) & 19.90 & 19.375 & 20.075 & 19.65 \\
& {$[11,28]$} & {$[9,25]$} & {$[11,30]$} & {$[10,28]$} \\
Conscientiousness (B5) & 10.550 & 10.825 & 10.775 & 10.600 \\
& {$[3,15]$} & {$[6,15]$} & {$[6,15]$} & {$[6,13]$} \\
Extraversion (B5) & 9.875 & 10.025 & 10.675 & 10.800 \\
Agreeableness (B5) & {$[5,14]$} & {$[5,15]$} & {$[5,15]$} & {$[5,15]$} \\
Neuroticism (B5) & 10.850 & 10.725 & 11.025 & 11.150 \\
& {$[5,15]$} & {$[6,15]$} & {$[5,15]$} & {$[5,14]$} \\
& 10.95 & 11.025 & 11.15 & 11.85 \\
& {$[6,14]$} & {$[6,14]$} & {$[6,15]$} & {$[8,15]$} \\
& 8.8 & 9.175 & 8.7 & 9 \\
& {$[3,15]$} & {$[4,15]$} & {$[3,15]$} & {$[5,15]$} \\
\hline
\end{tabular}

* Half of the questionnaire data in this treatment were lost due to a server crash.

Table 3: Mean and range for a number of variables.

Table 3 summarizes some statistics (mean and range) of our sample. The information on sample characteristics was collected in a post experimental questionnaire, and unfortunately for the treatment NonMarketSCinfo, questionnaire data were lost for half of the participants due to a server crash. With this caveat, our sample appears gender balanced across all treatments with the share of men ranging between $37-55 \%$. On average participants are about 21 years old, but age ranges between 18 and 27 . The table also reports a number of measures on risk aversion, cognitive ability, machiavellianism, competitiveness and optimism as well as the Big5 personality traits elicited as described in detail in Appendix D.

Figure 8 illustrates the cdfs for age, risk aversion and cognitive ability, Machiavellianism, competitiveness and optimism. The figure illustrates that, despite some differences in means, the overall distributions do not substantially differ; only on cognitive ability participants in the Market treatment seem to score somewhat higher, though there are no differences between our key treatments Market-SCinfo and Nonmarket-SCinfo ( $p=0.2135$, two-sided ranksum test based on $n=60$ observations). Figure 9 illustrates the cdfs for the Big5 personality traits. Again, there are no notable differences across treatments. Table 8 in Appendix G 
includes all controls in our main regression (Equation (1)) and shows that coefficient sizes $\beta_{1}+\beta_{3}$ and $\beta_{2}+\beta_{3}$ as well as statistical significance tend to increase after including all 11 variables from the questionnaire as controls.

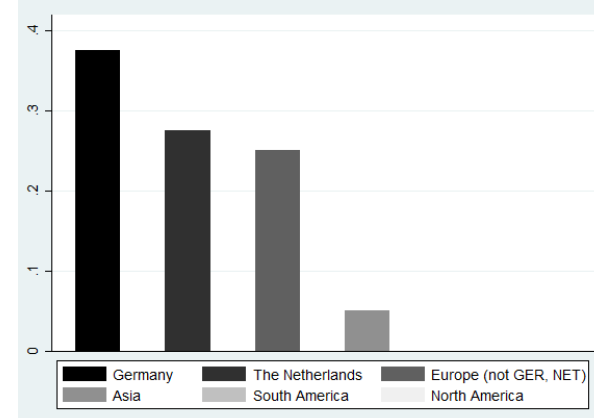

(a) Market

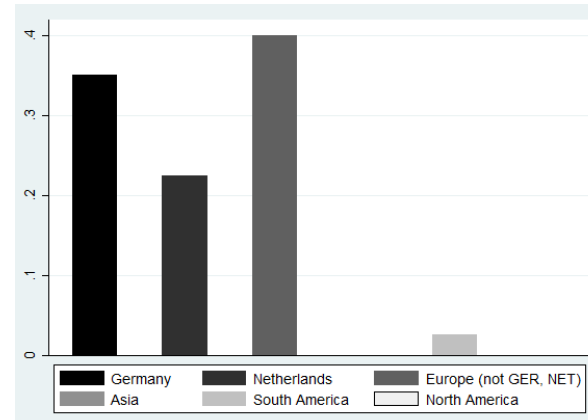

(c) NonMarket

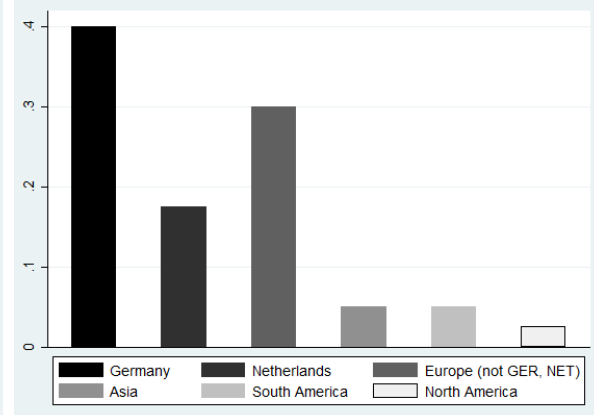

(b) Market-SCinfo

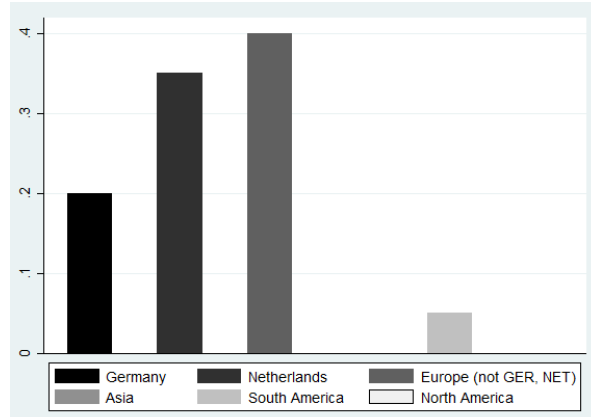

(d) NonMarket-SCinfo

Figure 7: Country or region of participants' nationalities.

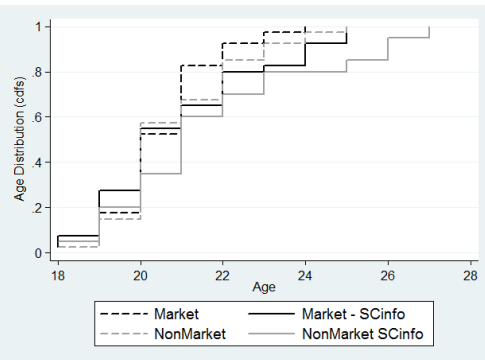

(a) Age



(d) Machiavellianism

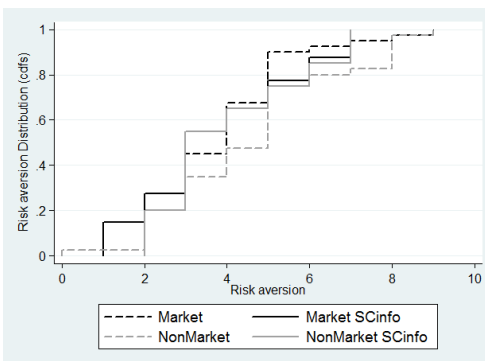

(b) Risk aversion measure

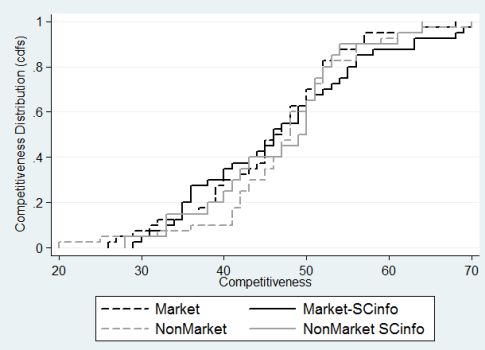

(e) Competitiveness



(c) Cognitive ability



(f) Optimism

Figure 8: A number of sample characteristics (cdfs). 


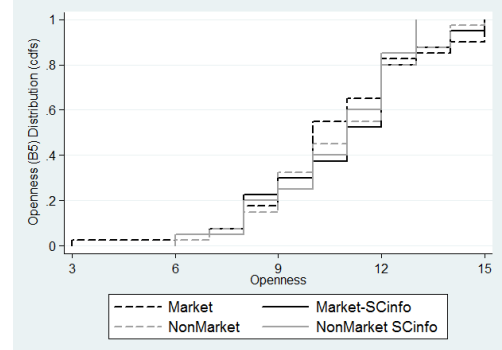

(a) Openness (B5)



(d) Agreeableness (B5)



(b) Conscientiousness (B5)

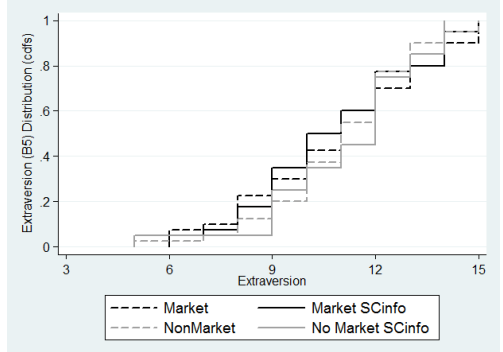

(c) Extraversion (B5)

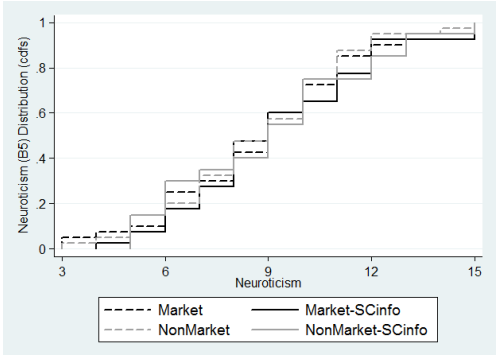

(e) Neuroticism (B5)

Figure 9: A number of sample characteristics (cdfs). 


\section{F Social Comparison in Markets}

Assume player $i$ holds the high risk asset and player $j$ the low risk asset, then $i$ 's utility is given by

$$
\begin{array}{r}
V_{i}^{H R}=\eta E U^{H R}+\psi\left[\frac{7}{25} v(0)+\frac{6}{25} v(u(50)-u(100))+\frac{2}{25} v(u(50)-u(150))+\frac{1}{25} v(u(100)-u(50))\right. \\
\left.+\frac{1}{25} v(u(100)-u(150))+\frac{2}{25} v(u(150)-u(50))+\frac{6}{25} v(u(150)-u(100))\right] .
\end{array}
$$

For the low risk asset the expression is analogous. The risk premium $R P$ should then equal

$$
\begin{aligned}
R P= & V_{i}^{L R}-V_{i}^{H R} \\
= & \eta\left(E U^{L R}-E U^{H R}\right)+\psi\left[\frac{5}{25}\{v(u(100)-u(50))-v(u(50)-u(100))\right. \\
& \quad+v(u(100)-u(150))-v(u(150)-u(100))\}] .
\end{aligned}
$$

Or, when denoting $y=u(100)-u(50)$ and $x=u(150)-u(100)$,

$$
R P=\eta\left(E U^{L R}-E U^{H R}\right)+\frac{1}{5} \psi[v(y)-v(-y)+v(-x)-v(x)],
$$

where $y \geq x>0$ by concavity of $u$. The term in the squared brackets is nonnegative if $v$ is linear or strictly convex in the loss domain and concave in the gains domain. ${ }^{2}$ Hence, $R P$ is increasing in $\psi$.

\footnotetext{
${ }^{2}$ Because of loss aversion we know that $\left|v^{\prime}(x)\right|<\left|v^{\prime}(-x)\right|$. Convexity in the loss domain means $\left|v^{\prime}(x)\right|<\left|v^{\prime}(-y)\right|$.
} 


\section{G Additional Tables}

Table 4 shows descriptive statistics (mean and range across all 30 periods) for a number of different variables. It can be seen that the risk premium is highest in the market treatment with SC information and that this is due to both a higher ask and a higher bid premium (defined as the difference between asks and bids, respectively, between the less risky and more risky asset). Prices tend to be somewhat lower in the market treatments, mostly due to lower asks, but the differences are relatively small. The volume of trade is highest in the market treatment without SC information and decreases both as SC information is added or market interaction is taken away. In all treatments and groups there was at least one trade in each round, though not always both assets were traded.

\begin{tabular}{|c|c|c|c|c|}
\hline & Market & Market-SCinfo & NonMarket & NonMarket-SCinfo \\
\hline Bid low risk asset & $\begin{array}{c}62.98 \\
{[50,150]}\end{array}$ & $\begin{array}{c}70.14 \\
{[50,150]}\end{array}$ & $\begin{array}{c}68.31 \\
{[50,150]}\end{array}$ & $\begin{array}{c}70.27 \\
{[50,150]}\end{array}$ \\
\hline Ask low risk asset & $\begin{array}{c}79.96 \\
{[50,150]}\end{array}$ & $\begin{array}{c}92.78 \\
{[50,150]}\end{array}$ & $\begin{array}{c}93.70 \\
{[50,150]}\end{array}$ & $\begin{array}{c}97.61 \\
{[50,150]}\end{array}$ \\
\hline Price low risk asset & $\begin{array}{c}67.06 \\
{[50,125]}\end{array}$ & $\begin{array}{c}76.90 \\
{[50,110]}\end{array}$ & $\begin{array}{c}77.71 \\
{[52.5,122.5]}\end{array}$ & $\begin{array}{c}80.90 \\
{[57.5,122]}\end{array}$ \\
\hline Bid high risk asset & $\begin{array}{c}63.16 \\
{[50,150]}\end{array}$ & $\begin{array}{c}66.26 \\
{[50,149]}\end{array}$ & $\begin{array}{c}69.05 \\
{[50,150]}\end{array}$ & $\begin{array}{c}70.00 \\
{[50,150]}\end{array}$ \\
\hline Ask high risk asset & $\begin{array}{c}81.14 \\
{[50,150]}\end{array}$ & $\begin{array}{c}89.52 \\
{[50,150]}\end{array}$ & $\begin{array}{c}92.80 \\
{[50,150]}\end{array}$ & $\begin{array}{c}100.13 \\
{[50,150]}\end{array}$ \\
\hline Price high risk asset & $\begin{array}{c}66.14 \\
{[50,105]}\end{array}$ & $\begin{array}{c}71.99 \\
{[50,109]}\end{array}$ & $\begin{array}{c}76.71 \\
{[50,125]}\end{array}$ & $\begin{array}{c}81.58 \\
{[53,122]}\end{array}$ \\
\hline Bid premium & $\begin{array}{c}0.17 \\
{[-100,100]}\end{array}$ & $\begin{array}{c}3.88 \\
{[-75,100]}\end{array}$ & $\begin{array}{c}-0.73 \\
{[-100,100]}\end{array}$ & $\begin{array}{c}0.27 \\
{[-95,99]}\end{array}$ \\
\hline Ask premium & $\begin{array}{c}-1.18 \\
{[-100,100]}\end{array}$ & $\begin{array}{c}3.26 \\
{[100,100]}\end{array}$ & $\begin{array}{c}0.90 \\
{[-100,100]}\end{array}$ & $\begin{array}{c}-2.51 \\
{[-97,100]}\end{array}$ \\
\hline Risk premium & $\begin{array}{c}1.08 \\
{[-33.5,35]}\end{array}$ & $\begin{array}{c}5.59 \\
{[-27.5,45]}\end{array}$ & $\begin{array}{c}1.16 \\
{[-42.5,42.5]}\end{array}$ & $\begin{array}{c}-0.48 \\
{[-37.5,33]}\end{array}$ \\
\hline Quantity traded low risk asset & $\begin{array}{l}1.70 \\
{[0,3]}\end{array}$ & $\begin{array}{l}1.58 \\
{[0,4]}\end{array}$ & $\begin{array}{l}1.36 \\
{[0,3]}\end{array}$ & $\begin{array}{l}1.17 \\
{[0,2]}\end{array}$ \\
\hline Quantity traded high risk asset & $\begin{array}{l}1.90 \\
{[0,4]}\end{array}$ & $\begin{array}{l}1.60 \\
{[0,3]}\end{array}$ & $\begin{array}{l}1.53 \\
{[0,3]}\end{array}$ & $\begin{array}{l}1.23 \\
{[0,2]}\end{array}$ \\
\hline Total number of trades & 868 & 766 & 697 & 577 \\
\hline
\end{tabular}

Table 4: Mean and range for a number of variables.

Table 5 shows the results of running regression (1) separately for the two signal distributions $\rho_{1}$ and $\rho_{2}$ (see Table 2). It can be seen that the effects uncovered above are driven mainly by signal distribution $\rho_{2}$, though the direction of the effects is the same under $\rho_{1}$ (see also Figure 10). This suggests that information matters for the size of the effect, though the direction is the same under both distributions.

Table 6 shows a regression, where instead of risk premia we regress price on our market and SC information dummies. The table shows that prices for the high risk asset in the market treatment with SC information are lower than those in the corresponding nonmarket treatment $\left(\beta_{1}+\beta_{3}<0\right)$ and that $\mathrm{SC}$ information increases prices for the low risk asset in the market setting, but not the nonmarket setting $\left(\beta_{2}+\beta_{3}>0 ; \beta_{2}=0\right)$. It also shows that in the absence of SC information market prices for all assets are lower under the market condition compared to the nonmarket condition.

Table 7 shows the evolution of the risk premium over time in the different treatments. Even columns 


\begin{tabular}{|c|c|c|c|c|}
\hline & (1) & (2) & (3) & (4) \\
\hline & All & $26-30$ & All & $26-30$ \\
\hline Constant $(\alpha)$ & $\begin{array}{c}1.140 \\
(4.472)\end{array}$ & $\begin{array}{c}2.700 \\
(5.652)\end{array}$ & $\begin{array}{r}-0.196 \\
(3.087)\end{array}$ & $\begin{array}{c}1.294 \\
(5.424)\end{array}$ \\
\hline Market $\left(\beta_{1}\right)$ & $\begin{array}{c}0.231 \\
(5.123)\end{array}$ & $\begin{array}{r}-2.900 \\
(6.047)\end{array}$ & $\begin{array}{c}2.915 \\
(5.068)\end{array}$ & $\begin{array}{r}-0.321 \\
(4.623)\end{array}$ \\
\hline $\operatorname{SCinfo}\left(\beta_{2}\right)$ & $\begin{array}{l}-2.601 \\
(3.908)\end{array}$ & $\begin{array}{r}-2.630 \\
(4.316)\end{array}$ & $\begin{array}{c}0.738 \\
(2.822)\end{array}$ & $\begin{array}{r}-4.371 \\
(8.251)\end{array}$ \\
\hline SCinfo $\times$ Market $\left(\beta_{3}\right)$ & $\begin{array}{c}3.802 \\
(4.523)\end{array}$ & $\begin{array}{l}10.13^{*} \\
(6.133)\end{array}$ & $\begin{array}{c}6.030 \\
(5.796)\end{array}$ & $\begin{array}{l}16.10^{* * *} \\
(5.829)\end{array}$ \\
\hline $\begin{array}{l}\beta_{1}+\beta_{3} \\
p \text {-value test } \beta_{1}+\beta_{3}=0\end{array}$ & $\begin{array}{l}4.033 \\
0.457\end{array}$ & $\begin{array}{l}7.230 \\
0.537\end{array}$ & $\begin{array}{l}8.945^{* * *} \\
0.005\end{array}$ & $\begin{array}{l}15.779^{* * *} \\
<0.001\end{array}$ \\
\hline $\begin{array}{l}\beta_{2}+\beta_{3} \\
p \text {-value test } \beta_{2}+\beta_{3}=0\end{array}$ & $\begin{array}{l}1.201 \\
0.770\end{array}$ & $\begin{array}{l}7.500 \\
0.325\end{array}$ & $\begin{array}{l}6.768 \\
0.152\end{array}$ & $\begin{array}{r}11.729 \\
0.148\end{array}$ \\
\hline Observations & 440 & 76 & 440 & 76 \\
\hline Number of groups & 32 & 16 & 32 & 16 \\
\hline Signal & $\rho_{1}$ & $\rho_{1}$ & $\rho_{2}$ & $\rho_{2}$ \\
\hline
\end{tabular}

Table 5: Risk premium regressed on market and SC information dummies separately for $\rho_{1}$ and $\rho_{2}$.

\begin{tabular}{lccccc}
\hline & \multicolumn{2}{c}{ Low risk asset } & & \multicolumn{2}{c}{ High risk asset } \\
\cline { 2 - 3 } \cline { 5 - 6 } & $(1)$ & $(2)$ & & $(3)$ & $(4)$ \\
& All & $26-30$ & & All & $26-30$ \\
\hline Constant $(\alpha)$ & $77.65^{* * *}$ & $76.42^{* * *}$ & & $76.63^{* * *}$ & $74.38^{* * *}$ \\
Market $\left(\beta_{1}\right)$ & $(2.843)$ & $(3.216)$ & & $(2.672)$ & $(4.576)$ \\
& $-10.32^{* * *}$ & $-12.91^{* * *}$ & & $-10.51^{* * *}$ & -11.22 \\
SCinfo $\left(\beta_{2}\right)$ & $(3.813)$ & $(4.853)$ & & $(3.352)$ & $(7.024)$ \\
& 3.585 & 3.125 & & 5.269 & 7.046 \\
SCinfo $\times$ Market $\left(\beta_{3}\right)$ & $(4.181)$ & $(5.671)$ & & $(4.544)$ & $(9.189)$ \\
& 6.087 & 9.388 & & 0.769 & -4.183 \\
$\beta_{1}+\beta_{3}$ & $(6.239)$ & $(10.94)$ & & $(5.167)$ & $(10.86)$ \\
$p$-value test $\beta_{1}+\beta_{3}=0$ & -4.322 & -3.522 & & $-9.741^{* * *}$ & $-15.403^{* *}$ \\
$\beta_{2}+\beta_{3}$ & 0.167 & 0.620 & & 0.007 & 0.041 \\
$p$-value test $\beta_{2}+\beta_{3}=0$ & $9.672^{* *}$ & $12.513^{*}$ & & 6.038 & 2.863 \\
\hline Observations & 0.045 & 0.091 & & 0.108 & 0.601 \\
\hline Number of groups & 911 & 159 & & 929 & 153 \\
\hline & 32 & 32 & & 32 & 32 \\
\hline
\end{tabular}

Table 6: Market prices for the two assets. 


\begin{tabular}{|c|c|c|c|c|c|c|c|c|}
\hline & \multicolumn{2}{|c|}{ Market } & \multicolumn{2}{|c|}{ Market-SCinfo } & \multicolumn{2}{|c|}{ NonMarket } & \multicolumn{2}{|c|}{ NonMarket-SCinfo } \\
\hline & (1) & $(2)$ & (3) & (4) & (5) & $(6)$ & (7) & $(8)$ \\
\hline Constant & $\begin{array}{c}4.401 \\
(9.979)\end{array}$ & $\begin{array}{c}2.331 \\
(4.390)\end{array}$ & $\begin{array}{c}-0.202 \\
(9.100)\end{array}$ & $\begin{array}{c}1.492 \\
(4.686)\end{array}$ & $\begin{array}{c}-0.626 \\
(5.812)\end{array}$ & $\begin{array}{c}-0.111 \\
(3.508)\end{array}$ & $\begin{array}{r}4.833 \\
(15.86)\end{array}$ & $\begin{array}{c}1.215 \\
(4.349)\end{array}$ \\
\hline Repetition & $\begin{array}{r}-0.908 \\
(3.719)\end{array}$ & & $\begin{array}{c}1.675 \\
(3.132)\end{array}$ & & $\begin{array}{r}-1.577 \\
(2.457)\end{array}$ & & $\begin{array}{c}-2.901 \\
(6.288)\end{array}$ & \\
\hline Trading period (TP) & $\begin{array}{c}-0.390 \\
(1.123)\end{array}$ & & $\begin{array}{c}0.174 \\
(1.325)\end{array}$ & & $\begin{array}{c}0.388 \\
(0.520)\end{array}$ & & $\begin{array}{c}-0.491 \\
(2.270)\end{array}$ & \\
\hline Repetition $\times \mathrm{TP}$ & $\begin{array}{c}0.057 \\
(0.430)\end{array}$ & & $\begin{array}{c}0.126 \\
(0.458)\end{array}$ & & $\begin{array}{c}0.078 \\
(0.266)\end{array}$ & & $\begin{array}{c}0.428 \\
(0.891)\end{array}$ & \\
\hline Period & & $\begin{array}{r}-0.082 \\
(0.186)\end{array}$ & & $\begin{array}{c}0.258 \\
(0.190)\end{array}$ & & $\begin{array}{r}-0.041 \\
(0.209)\end{array}$ & & $\begin{array}{r}-0.010 \\
(0.219)\end{array}$ \\
\hline Observations & \multicolumn{2}{|c|}{233} & \multicolumn{2}{|c|}{227} & \multicolumn{2}{|c|}{199} & \multicolumn{2}{|c|}{221} \\
\hline Number of groups & \multicolumn{2}{|c|}{8} & \multicolumn{2}{|c|}{8} & \multicolumn{2}{|c|}{8} & \multicolumn{2}{|c|}{8} \\
\hline
\end{tabular}

Table 7: Evolution of risk premium over time.

simply regress risk premium on period (1-30). Odd columns regress risk premium on "Trading period" (1-10), "Repetition" (1-3) as well as their interaction. The table shows that while risk premia tend to increase over time in Market-SCinfo, they tend to decrease in all other treatments, even though none of these trends appears statistically significant.

Table 8 repeats the regression from Equation (1), but includes in even columns all 11 variables elicited in the post experimental questionnaire described in Appendix D (descriptive statistics on these variables can be found in Appendix E). A number of characteristics affect the risk premium: risk aversion and cognitive ability of market participants tend to increase risk premia, while optimism, conscientiousness and neuroticism tend to decrease the risk premium. The risk premium is also lower if there are more male participants in a market. Importantly, our coefficients of interest $\left(\beta_{1}+\beta_{3}\right.$ and $\left.\beta_{2}+\beta_{3}\right)$ do not change much when questionnaire variables are included. If at all, effect sizes tend to increase upon including controls. Including the controls from the questionnaire also improves statistical significance, despite a loss of observations due to missing questionnaire variables for one session (see Appendix D).

Comparing odd and even columns suggests that multicollinearity does not seem too much of an issue. Table 9 shows pairwise correlation coefficients between questionnaire variables at the individual level across all treatments $(n=140)$. The table shows that generally correlation coefficients tend to be small and statistically insignificant. A few variables are significantly correlated however: men tend to be less risk averse $(\rho=-0.270)$, more competitive $(\rho=0.317)$ and less neurotic $(\rho=-0.344)$ than women. In addition neuroticism is positively correlated with risk aversion and negatively with optimism and extraversion. Machiavellianism is negatively correlated with optimism and agreeableness. At the matching group level only three of these correlations survive as statistically significant: the negative correlation between neuroticism and gender and optimism, respectively and the negative correlation between agreeableness and machiavellianism. Overall, Table 9 together with the fact that effect sizes and direction of our main variables are not affected too much by including questionnaire variables make us confident that multi-collinearity is not too much of a problem in the regression displayed in Table 8. The condition number for all thirteen variables reported in Table 9 is 81.5692, which is below the cutoff of 100 mentioned in Cameron and Trivedi (2005). 


\begin{tabular}{|c|c|c|c|c|}
\hline & $(1)$ & $(2)$ & $(3)$ & $(4)$ \\
\hline & All & All & $26-30$ & $26-30$ \\
\hline Constant $(\alpha)$ & $\begin{array}{c}1.042 \\
(2.094)\end{array}$ & $\begin{array}{l}88.19^{* * *} \\
(30.64)\end{array}$ & $\begin{array}{c}2.034 \\
(3.590)\end{array}$ & $\begin{array}{c}33.80 \\
(59.53)\end{array}$ \\
\hline Market $\left(\beta_{1}\right)$ & $\begin{array}{c}0.008 \\
(3.121)\end{array}$ & $\begin{array}{r}-3.608 \\
(2.892)\end{array}$ & $\begin{array}{r}-1.642 \\
(3.516)\end{array}$ & $\begin{array}{r}-3.527 \\
(3.645)\end{array}$ \\
\hline $\operatorname{SCinfo}\left(\beta_{2}\right)$ & $\begin{array}{r}-1.982 \\
(1.617)\end{array}$ & $\begin{array}{c}1.321 \\
(4.480)\end{array}$ & $\begin{array}{r}-3.480 \\
(4.241)\end{array}$ & $\begin{array}{r}-4.666 \\
(5.133)\end{array}$ \\
\hline SCinfo $\times$ Market $\left(\beta_{3}\right)$ & $\begin{array}{l}6.556^{* *} \\
(3.151)\end{array}$ & $\begin{array}{l}11.11^{*} \\
(5.939)\end{array}$ & $\begin{array}{l}13.09^{* * *} \\
(4.028)\end{array}$ & $\begin{array}{l}20.72^{* * *} \\
(5.705)\end{array}$ \\
\hline Gender & & $\begin{array}{r}-15.99^{* *} \\
(5.714)\end{array}$ & & $\begin{array}{r}-10.87^{*} \\
(6.536)\end{array}$ \\
\hline Age & & $\begin{array}{r}-2.058 \\
(1.623)\end{array}$ & & $\begin{array}{c}2.683 \\
(1.831)\end{array}$ \\
\hline Risk aversion & & $\begin{array}{l}2.803^{* *} \\
(1.374)\end{array}$ & & $\begin{array}{l}3.946^{\text {*** }} \\
(1.499)\end{array}$ \\
\hline Cognitive ability & & $\begin{array}{l}1.002^{\text {*** }} \\
(0.249)\end{array}$ & & $\begin{array}{l}1.087^{*} \\
0.583\end{array}$ \\
\hline Machiavellianism & & $\begin{array}{c}-0.268 \\
(0.218)\end{array}$ & & $\begin{array}{c}-0.714^{* *} \\
(0.324)\end{array}$ \\
\hline Competitiveness & & $\begin{array}{c}0.312^{*} \\
(0.164)\end{array}$ & & $\begin{array}{c}0.558^{* *} \\
(0.268)\end{array}$ \\
\hline Optimism & & $\begin{array}{c}-1.745^{* *} \\
(0.696)\end{array}$ & & $\begin{array}{c}-2.657^{* *} \\
(1.046)\end{array}$ \\
\hline Openness (B5) & & $\begin{array}{c}3.742^{* *} \\
(1.734)\end{array}$ & & $\begin{array}{c}1.310 \\
(1.392)\end{array}$ \\
\hline Conscientiousness (B5) & & $\begin{array}{c}-3.662^{\text {*** }} \\
(0.989)\end{array}$ & & $\begin{array}{c}-5.390^{* * *} \\
(1.000)\end{array}$ \\
\hline Extraversion (B5) & & $\begin{array}{c}1.492 \\
(1.440)\end{array}$ & & $\begin{array}{c}3.552^{* *} \\
(1.388)\end{array}$ \\
\hline Agreeableness (B5) & & $\begin{array}{r}-1.876 \\
(2.941)\end{array}$ & & $\begin{array}{c}0.209 \\
(0.970)\end{array}$ \\
\hline Neuroticism (B5) & & $\begin{array}{c}-5.793^{* * *} \\
(1.144)\end{array}$ & & $\begin{array}{c}-8.342^{* * *} \\
(1.268)\end{array}$ \\
\hline $\begin{array}{l}\beta_{1}+\beta_{3} \\
p \text {-value test } \beta_{2}+\beta_{3}=0\end{array}$ & $\begin{array}{l}6.564^{*} \\
0.073\end{array}$ & $\begin{array}{l}7.502^{* *} \\
0.041\end{array}$ & $\begin{array}{c}11.448^{* *} \\
0.044\end{array}$ & $\begin{aligned} & 17.193^{* * *} \\
< & 0.001\end{aligned}$ \\
\hline $\begin{array}{l}\beta_{2}+\beta_{3} \\
p \text {-value test } \beta_{2}+\beta_{3}=0\end{array}$ & $\begin{array}{l}4.574 \\
0.195\end{array}$ & $\begin{array}{l}12.431^{* * *} \\
<0.001\end{array}$ & $\begin{array}{l}9.610^{*} \\
0.063\end{array}$ & $\begin{aligned} & 16.054^{* * *} \\
< & 0.001\end{aligned}$ \\
\hline Observations & 880 & 779 & 152 & 134 \\
\hline Number of groups & 32 & 28 & 32 & 28 \\
\hline
\end{tabular}

Table 8: Random effects OLS regression including controls from post-experimental questionnaire (averaged for matching groups). 


\begin{tabular}{|c|c|c|c|c|c|c|c|c|c|c|c|c|}
\hline & (a) & (b) & (c) & (d) & (e) & (f) & $(\mathrm{g})$ & (h) & (i) & (j) & $(\mathrm{k})$ & (l) \\
\hline gender (a) & 1 & & & & & & & & & & & \\
\hline age (b) & 0.165 & 1 & & & & & & & & & & \\
\hline risk aversion (c) & $-0.270^{*}$ & -0.036 & 1 & & & & & & & & & \\
\hline competitiveness (e) & $0.317^{*}$ & 0.026 & -0.192 & 0.113 & 1 & & & & & & & \\
\hline optimism (f) & 0.064 & 0.032 & -0.067 & $-0.235^{*}$ & 0.118 & 1 & & & & & & \\
\hline openness (g) & 0.091 & 0.015 & -0.076 & 0.035 & 0.162 & 0.058 & 1 & & & & & \\
\hline agreeableness (j) & 0.023 & 0.024 & -0.094 & $-0.292^{*}$ & -0.013 & 0.163 & 0.057 & $0.257^{*}$ & 0.118 & 1 & & \\
\hline neuroticism $(\mathrm{k})$ & $-0.344^{*}$ & -0.064 & $0.236^{*}$ & 0.050 & -0.172 & $-0.552^{*}$ & 0.006 & 0.013 & $-0.140^{*}$ & 0.072 & 1 & \\
\hline cognitive ability (l) & -0.039 & $-0.060^{*}$ & -0.149 & 0.083 & 0.083 & $0.112^{*}$ & 0.076 & -0.042 & -0.014 & 0.091 & 0.010 & 1 \\
\hline
\end{tabular}

Table 9: Pairwise correlation coefficients between questionnaire variables at the individual level across all treatments. 


\section{H Additional Figures}

Figure 10 shows the risk premium over time for the two different signal distributions. The figure illustrates a pattern noted in Table 5 in Appendix G: with SC information risk premia are higher in the market compared to the nonmarket condition. This effect is obtained under both signal distribution, but is stronger under $\rho_{2}$, where more participants receive a pair of signals suggesting that the high risk asset yields higher returns.

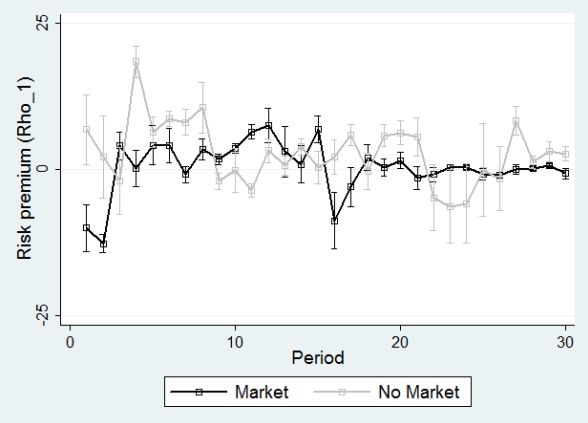

(a) without SC info; signal $\operatorname{distr} \rho_{1}$



(c) without SC info; signal distr $\rho_{2}$

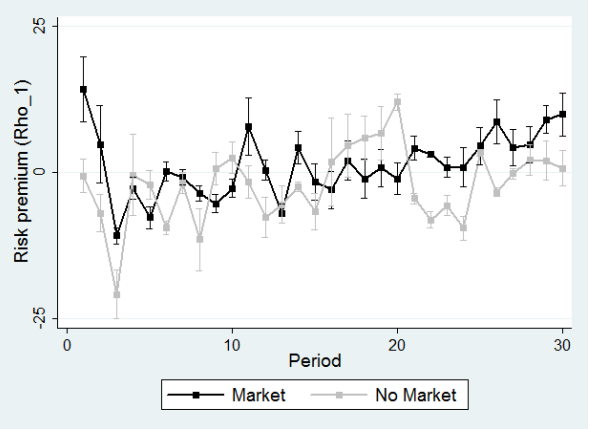

(b) with SC info; signal distr $\rho_{1}$

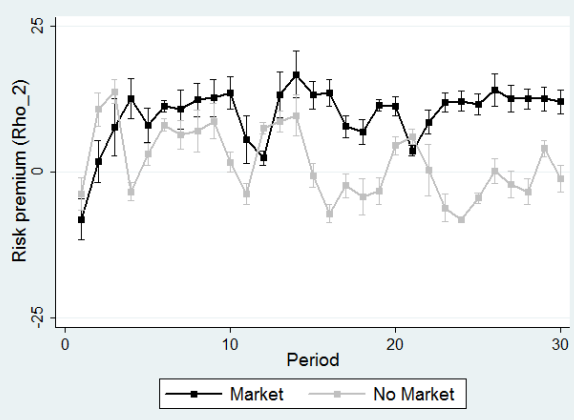

(d) with SC info; signal distr $\rho_{2}$

Figure 10: Risk premium for different signal distributions. 


\section{Alternative Nonmarket Treatment}

We also conducted a second nonmarket treatment variation, where instead of using the BDM mechanism to generate a price, we ask participants to correctly predict the expected value of the asset using the "Most Likely Interval elicitation rule" (Schlag and van der Weele, 2015). Figure 11 shows the risk premium over time including these alternative nonmarket treatments and illustrates qualitatively similar patterns. More details on this treatment and results are available upon request.

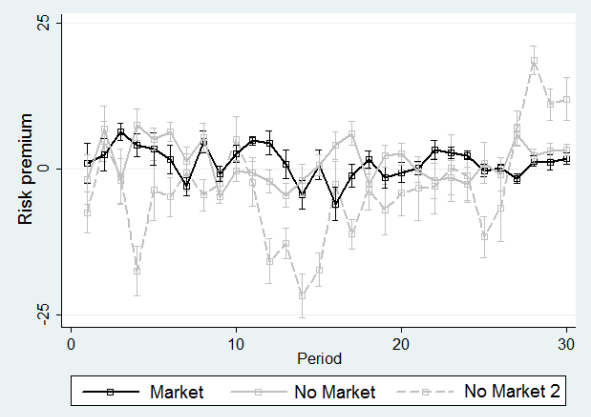

(a) without SC information

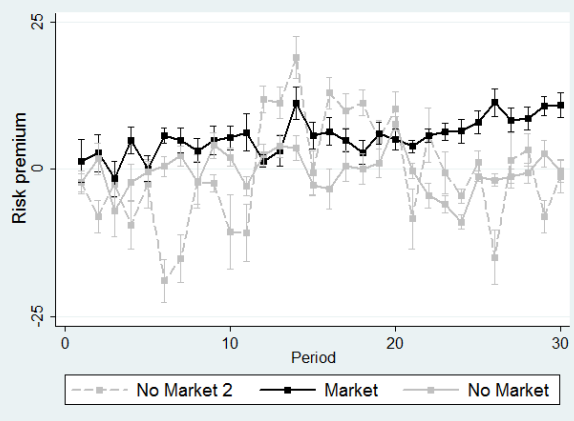

(b) with SC information

Figure 11: Risk premium including the alternative nonmarket treatments. 


\section{References Supplementary Material}

Cameron, A. C., and Trivedi, P. K. (2005), Microeconometrics: Methods and Applications, Cambridge: Cambridge University Press.

Christie, R. and F. Geis (1970). How devious are you? Take the Machiavelli test to find out. Journal of Management in Engineering 15.4: 17.

Costa, P.T. Jr. and R.R. McCrae (1992). Revised NEO Personality Inventory (NEO-PI-R) and NEO FiveFactor Inventory (NEO-FFI) manual. Odessa, FL: Psychological Assessment Resources.

Dohmen T., A. Falk, D. Huffman and U. Sunde (2010). Are risk aversion and impatience related to cognitive ability? The American Economic Review 100(3): 1238-1260.

Dohmen T., A. Falk, D. Huffman, U. Sunde, J. Schupp and G. Wagner (2011). Individual risk attitudes: Measurement, determinants and behavioral consequences. Journal of the European Economic Association $9(3)$ : $522-550$.

Houston, J.M., P.B. Harris, S. McIntire and D. Francis (2002). Revising the Competitiveness Index using factor analysis. Psychological Reports 90: 31-34.

Scheier, M.F., C.S. Carver and M.W. Bridges (1994). Distinguishing optimism from neuroticism (and trait anxiety, self-mastery, and self-esteem): A re-evaluation of the Life Orientation Test. Journal of Personality and Social Psychology 67: 1063-1078.

Schlag, K. H. and J. van der Weele (2015). A method to elicit beliefs as most likely intervals. Judgement and Decision Making 10(5), 456-468.

Veiga, H. and M. Vorsatz (2009). Price manipulation in an experimental asset market. European Economic Review 53, 327342 . 